\title{
Reconceptualizing What and How Women Negotiate for Career Advancement
}

\section{Citation}

Bowles, Hannah Riley, Thomason, Bobbi J., Bear, Julia B. 2019. "Reconceptualizing What and How Women Negotiate for Career Advancement." Academy of Management Journal. https:// doi.org/10.5465/amj.2017.1497

\section{Permanent link}

http://nrs.harvard.edu/urn-3:HUL.InstRepos:39145543

\section{Terms of Use}

This article was downloaded from Harvard University's DASH repository, and is made available under the terms and conditions applicable to Open Access Policy Articles, as set forth at http:// nrs.harvard.edu/urn-3:HUL.InstRepos:dash.current.terms-of-use\#OAP

\section{Share Your Story}

The Harvard community has made this article openly available.

Please share how this access benefits you. Submit a story.

Accessibility 


\title{
RECONCEPTUALIZING WHAT AND HOW WOMEN NEGOTIATE FOR CAREER ADVANCEMENT
}

HANNAH RILEY BOWLES

John F. Kennedy School of Government

Harvard University

79 JFK Street

Cambridge, MA 02138

email: hannah_bowles@hks.harvard.edu

BOBBI THOMASON

Graziadio Business School

Pepperdine University

24255 Pacific Coast Highway

Malibu, CA 90263

email: bobbi.thomason@pepperdine.edu

\author{
JULIA B. BEAR \\ College of Business \\ Stony Brook University \\ Harriman Hall \\ Stony Brook, NY 11794 \\ email: julia.bear@stonybrook.edu
}

IN PRESS AT ACADEMY OF MANAGEMENT JOURNAL

(fine to circulate or share)

\section{AUTHOR NOTE}

This work was supported by grants from the Harvard Kennedy School (HKS) Center for Public

Leadership and the HKS Women and Public Policy Program. We gratefully acknowledge

generous feedback on this manuscript from Robin Ely, Kathleen McGinn, Maureen Scully,

Elaine Backman, and the Qualitative Workshop at New York University. We owe special thanks

for the diligent research assistance of Alyson Gounden Rock. 


\begin{abstract}
We propose a conceptual framework for expanding the scope of future research on the role of gender in career negotiations. Extant research on gender in career negotiations emphasizes women's disadvantages relative to men in compensation negotiations. We present an inductive study of what and how women negotiate for career advancement and the attainment of leadership positions in organizations, drawing on data from diverse samples of negotiation accounts by senior-executive, mid-level, and early-career professionals from the public, private, and nonprofits sectors and six world regions. Integrating insights from six studies, we propose a more comprehensive perspective on what men and women negotiate for career advancement, including their role development and work-family conflicts, as well as compensation. We also identify three distinct negotiating strategies — asking, bending, and shaping - that vary in the extent to which the negotiator conforms to, deviates from, or attempts to redefine organization norms. Our analyses suggest that the choice of negotiating strategy has implications for men's and women's career progression, particularly for women's navigation of nontraditional career paths and men's and women's leadership claiming. We suggest new directions for research on the role of negotiation in career advancement and in promoting and mitigating gender inequality in organizations.
\end{abstract}




\section{RECONCEPTUALIZING WHAT AND HOW WOMEN NEGOTIATE FOR CAREER ADVANCEMENT}

Careers are a jungle gym, not a ladder

Patti Seller, Executive Director, Fortune's Most Powerful Women

There's only one way to get to the top of a ladder, but there are many ways to get to the top of a jungle gym.... A jungle gym provides views for many people, not just those at the top. On a ladder, most climbers are stuck staring at the butt of the person above.

Sheryl Sandberg, Lean In

The story of women's career advancement is about agency in context. It involves understanding the "labyrinths" of women's career advancement (Eagly \& Carli, 2007) and how women navigate them (Lyness \& Erkovan, 2016). The focus of the present research is on one specific form of agency in career advancement: how women negotiate to advance their climb upwards, sideways, and at times even downwards through the career jungle gym.

We define "negotiations" as interactive problem-solving processes that involve some tradeoffs or conflict to be resolved (Lax \& Sebenius, 1986; Raiffa, 1982; Thompson, 2005). We use the term "career" to refer to the progression of work-related experiences one has over one's life within and outside of organizational contexts (Arthur, Hall, \& Lawrence, 1989; Hall, 1972; Lyness \& Erkovan, 2016). By "self-advocacy in career negotiations," we mean situations in which individuals initiate or engage in negotiations for the purpose of achieving their career aspirations, including managing work-life conflicts. We refer to progress toward achieving career aspirations as "career advancement" or "career gains."

Negotiation scholars have made strides in explaining the effects of gender on selfadvocacy in negotiation (Kugler, Reif, Kaschner, \& Brodbeck, 2018; Mazei et al., 2015). A key finding is that women tend to be more hesitant than men to negotiate their job offers, particularly their pay (Amanatullah \& Morris, 2010; Bowles, Babcock, \& McGinn, 2005; Kray \& Gelfand, 2009; Kugler et al., 2018; Small, Gelfand, Babcock, \& Gettman, 2007). The leading explanation 
for women's lack of assertiveness in negotiating for higher compensation is social backlash. Gender norms prescribe that women put others before themselves and that men are the family breadwinners. Evaluators report less willingness to work with a woman if she agentically selfadvocates for higher pay as compared to if she lets the opportunity to negotiate pass- and women anticipate this reaction (Amanatullah \& Morris, 2010; Bowles, Babcock, \& Lai, 2007).

Negotiation scholars have speculated that these largely lab-based demonstrations of gender differences in the propensity to self-advocate in pay negotiations could help to explain the gender gap in organizational authority as well as pay, for instance, making the case that women do not advance because "women don't ask" (Babcock \& Laschever, 2003). Others challenge this contention, arguing that lab-based studies drain away the gendered organizational backdrop and rich variation in women's career negotiations over opportunities, resources, and authority (e.g., Kolb \& McGinn, 2009). In this research, we use a grounded-theory approach to advance research on the role of negotiation in women's career development in three important respects (see illustration in Figure 2). First, we integrate the study of role and workload negotiations with the study of gender effects on compensation negotiations. Second, we illuminate ways in which negotiation is an opportunity, as well as at times a problem, for women's career advancement. Third, reaching beyond the closed systems of laboratory research (Bendersky \& McGinn, 2010), we uncover how men and women negotiate to bend and shape organizational norms.

In our study, we inductively analyze the career negotiation accounts of more than 450 diverse male and female professionals. Drawing insights from these data and from literature on the gender pay gap and on explicit and implicit negotiation processes in organizational career advancement, we propose a conceptual framework for advancing research on gender in career negotiations. In closing, we propose new directions for organizationally grounded studies on the role of negotiation in men's and women's career advancement and leadership attainment. 


\section{THEORETICAL MOTIVATIONS}

\section{Pay Bargaining Dominates the Study of Gender in Career Negotiations}

To begin our inquiry, we conducted a review of studies of gender in career-related negotiations. We searched for negotiation studies comparing the behavior, performance, or evaluations of men and women self-advocating for some form of career advancement. (See Supplemental Materials for list of articles.) Among 44 studies identified (in 30 papers), 80\% were laboratory based, and 91\% —including all lab-based studies — focused exclusively on negotiating compensation and other job offer terms. Four field surveys inquired about men and women's propensity to negotiate for promotion or other resources. All studies reporting a female disadvantage focused on negotiations over compensation. The one study reporting evidence of women negotiating more than men included data on a broad range of career-related subjects (e.g., research funds, dual-career accommodations, etc.) (Mitchell \& Hesli, 2013).

In sum, we uncovered robust evidence to support the proposition that pay negotiations pose a distinctive set of challenges for women, particularly because they are counterstereotypical and commonly occur under conditions of ambiguity about the bargaining range and behavioral norms (Bowles et al., 2005; Kugler et al., 2018; Mazei et al., 2015). However, we were also left questioning whether a "streetlight effect" (Kaplan, 2017) might be obscuring a broader understanding of how men and women negotiate their careers. Pay negotiations are economically important (Gerhart \& Rynes, 1991), but they are also easier to study than other forms of career advancement. Monetary payoffs are readily quantifiable, and the organizational "script" (Gioia \& Poole, 1984) of a job-offer negotiation is so widely recognized that it is easily played out in a class- or lab-based study with a few pages of abstract information (e.g., Neale, 1997).

However, the societal gender pay gap is not simply a function of how much men and women earn at organizational entry or promotion points. It is explained largely by men's and 
women's career trajectories, particularly the gender segregation of occupations and time-greedy work (Blau \& Kahn, 2017; Goldin, 2014). In the book Through the Labyrinth, Eagly and Carli (2007: 8) argue for a better understanding of how women advance into leadership positions as a function of their individual agency as well as organizational policy and culture-including "roundabout or discontinuous or nontraditional routes to authority." In this spirit, we searched the organizations literature for evidence of negotiation processes beyond the scope of job offers that might inhibit or contribute to women's career advancement.

\section{Explicit and Implicit Negotiation Processes in Career Advancement}

To inform our theory development, we reviewed the organizations literature for examples of explicit and implicit negotiation processes that influence career advancement. The clearest explicit negotiation example was the study of idiosyncratic work arrangements (Miner, 1987) or “i-deals” (Rousseau, 2005; Rousseau, Ho, \& Greenberg, 2006). I-deals are non-standard, individualized work arrangements that employees negotiate and that employers typically grant to motivate and retain highly valued employees (Rousseau, 2005). Rousseau and colleagues have documented i-deals negotiated by men and women over a broad array of topics, from dress codes to sabbaticals to flexible work (Hornung \& Rousseau, 2008; Rousseau, 2005).

A literature with common threads to i-deals is the study of "job crafting" (Wrzesniewski \& Dutton, 2001). Job crafting about enhancing one's personal sense of meaning and identity at work. This may be achieved through individual choices (e.g., how to frame or enact one's responsibilities) but can also involve engagement with colleagues to alter the task or relational boundaries of one's work (Wrzesniewski, Dutton, \& Debebe, 2003). Though largely implicit, this literature suggests ways in which role negotiations could satisfy career aspirations.

Negotiation processes are implicit in studies of issue selling (Dutton \& Ashford, 1993) and leadership claiming (Derue \& Ashford, 2010). The literature on issue selling explains when 
and how middle managers raise top management's awareness of important organizational issues and sheds light on how upward influence processes could set the stage for career negotiations over a manager's role (Dutton \& Ashford, 1993). Leadership claiming is a theory of leadership ascension that involves an interactive process of bids for and concessions of authority that conceptually resembles a negotiation process (Derue \& Ashford, 2010).

Finally, the literature on flexible work arrangements represents another realm of implicit and explicit career negotiation processes. Flexible work arrangements are typically studied in terms of whether one has access to or takes advantage of formal organizational policies (e.g., maternity leave, telecommuting, reduced hours) (cf., Hornung \& Rousseau, 2008). Yet, numerous scholars stress that such arrangements and other family-friendly benefits require individual negotiation (Blair-Loy \& Wharton, 2002; Greenberg \& Landry, 2011; Kelly \& Kalev, 2006). For example, Kelly and Kalev (2006) found that flexible work arrangements are commonly administered by managerial discretion to valued employees who negotiate them.

The case of flexible work arrangements is particularly interesting in light of the literature on gender in pay negotiations because it suggests an inverse pattern of gender effects. Findings indicate that men face a similar dilemma when asking for flexible work accommodations as women face when asking for higher pay because of the gender-role incongruity (Vandello, Hettinger, Bosson, \& Siddiqi, 2013). Work-family accommodations are associated with feminine gender roles and contradict masculine-stereotypic "ideal worker" norms (Kelly, Ammons, Chermack, \& Moen, 2010; Reid, 2015; Rudman \& Mescher, 2013). Even when men and women value work flexibility and work-life balance equally, men (as compared to women) tend to be more hesitant to negotiate for it (Kelly et al., 2010; Vandello et al., 2013) and face a greater risk of experiencing "not man enough" backlash when they do (Berdahl \& Moon, 2013). Contrary to 
the overgeneralized premise that “women don’t ask” (Babcock \& Laschever, 2003), both men and women are challenged in counter-stereotypical career negotiations (Bear, 2011).

\section{OVERVIEW OF STUDIES}

To develop a conceptual framework for expanding research on gender in career negotiations in organizations (presented in Figure 2), we conducted six studies. Table 1 presents descriptive statistics of the participants in each sample. In Study 1, we conducted interviews with male and female senior government executives about their career-related negotiations. From our inductive analyses of these interviews, we developed a set of constructs concerning what and how managers negotiate for career advancement beyond asking for higher pay. In Study 2, we employed a survey instrument to test the external validity of these constructs with a novel population of private-sector executives. In Study 3, we aspired to develop a better understanding of the functions of these emergent negotiation constructs in women's career advancement by studying senior executive women's accounts of what and how they negotiated at pivotal career transitions. In Study 4, we compared and contrasted executive and non-executive women's career negotiation accounts, examining the career implications of what and how they described negotiating. In Studies 5 and 6, we aimed to test the boundaries of our constructs by studying failed and successful career negotiation accounts from senior executive (Study 5) and earlycareer (Study 6) samples of informants. Study 6 helped us sharpen our conceptualization of the career gains associated with what and how professionals negotiate.

\section{STUDY 1}

In Study 1, we sought to develop a grounded perspective on career negotiations. We conducted interviews with U.S. federal government executives about their career-related negotiations. We coded the negotiation accounts inductively with attention to what and how the executives described negotiating for vis-à-vis their career advancement. 
Because gender effects in negotiation tend to be moderated by whether negotiators are advocating for themselves or others (Amanatullah \& Morris, 2010; Bowles et al., 2007), we asked men and women to describe an experience negotiating something career-related for themselves and an experience negotiating something career-related for someone else. As is commonly observed, gender differences were more transparent in the self-advocacy than otheradvocacy examples (Mazei et al., 2015). There were no perceptible differences in men's and women's accounts of negotiating for others. For the sake of parsimony, we present only our analyses of participants' self-advocacy examples. Results using the same analyses described below on the other-advocacy examples are available upon request.

\section{Data Collection}

We interviewed 49 civil servants in the U.S. federal government (27 men, 22 women) who were participating in a university-based executive program. A primary function of the program is leadership development in preparation for promotion to the Senior Executive Service, the most senior level of the civil service. Therefore, all participants had approximately the same level of managerial seniority, but in a broad range of agencies (e.g., Energy, Defense, Health and Human Services, National Parks). See Table 1 for descriptive information on the interviewees.

One author conducted most of the interviews, with a handful completed by research assistants who assisted with pretesting of the interview protocol. We followed a structured protocol, presenting the purpose of the study as "to learn about career-related negotiations," including "negotiating over things like work assignments, training, promotions, or compensation." The interviewer explained, "By negotiation, we mean requests that involve some problem solving, creative tradeoffs, or compromise to be resolved." This introduction was followed by an open-ended question intended to bring to mind examples of career-related negotiations: "What types of career-related things can people negotiate for in your 
organization?" The interviewer then asked for an example of a career-related negotiation for oneself and for someone else, in counterbalanced order. To increase the accuracy of recall and facilitate comparative analysis of informants' accounts, we asked the executives to situate themselves in a specific career event and to recall concrete, factual information (Spradley, 1979) (e.g., with whom they negotiated, arguments they used, how long the negotiation lasted). We asked the executives to rate how they felt about the negotiating experience (5-pt scale: $1=$ very negative, $5=$ very positive). Finally, we inquired how often they engaged in career negotiations ( 1 = "once a week," 2 = "once a month," 3 = "once a quarter," 4 = "once a year or less"). The conversations lasted 30 to 60 minutes and were recorded and transcribed.

\section{Data Analysis}

In the first stage of our analysis, at least two authors reviewed each transcript to confirm that the interviewees' responses to the negotiation questions fit with our definition of a careerrelated negotiation: a career-related proposal or request that required some joint problem-solving with colleagues or superiors, including some tradeoffs or conflict to be resolved. We also confirmed whether the career negotiation accounts fit as intended with self-advocacy (i.e., negotiating for one's own career advancement) or other-advocacy (i.e., negotiating for someone else's career advancement). We removed cases in which the interviewee did not have a clear example or opted —in spite of probing — to describe how they negotiated in general (e.g., "know the background of the person..., then apply whatever political wealth you might have" [G11]).

Before analyzing the negotiation accounts, a research assistant removed all references to the gender of the interviewee (e.g., "As a woman, I...”). Following recognized methods of grounded theory building (Strauss \& Corbin, 1998), our coding system was emergent from the data and informed by our reading of relevant literature. We started by coding each example for the subject of negotiation. As we delved into the negotiation examples, we perceived systematic 
variation in the strategies described. Iterating between the data and the literature, we developed codes for three primary subjects of negotiation and three distinct negotiating strategies.

Primary subject of negotiation. We started with a preliminary list of nine subject categories (i.e., compensation and benefits, performance evaluation, promotion, training, work detail, work experience, work location, work schedule) and then refined our coding scheme by reexamining what appeared to be the primary motivations for the negotiations. We arrived at three primary subject categories: role, work-family conflict, and compensation. "Role" negotiations related to seeking an expansion of authority, enhanced responsibilities, and developmental opportunities (e.g., rotational role assignments, leadership program). "Workfamily" negotiations covered workload negotiations (e.g., hours, place of work, travel) when work-life issues or concerns were a salient motivating factor. "Compensation" negotiations related to salary, bonus, or other benefits (e.g., health insurance, moving expenses).

Negotiating strategies. We developed three codes for negotiating strategy—asking, bending, and shaping — which stemmed from two primary sources of variation in the negotiation accounts. First, we observed variation in the degree to which the employee's negotiation proposal aligned with or deviated from organizational norms (e.g., accepted policy or practice). Second, to the extent the proposal deviated from organizational norms, we perceived an important difference between proposals for one-off exceptions for personal benefit and proposals to change organizational practices or structures (e.g., reporting lines). "Asking” involved individual requests or proposals for career advancement that would be recognized as standard issues and options for discussion between employee and employer, akin to the negotiation exercises commonly used in laboratory studies and teaching. "Bending" involved requests or proposals for individual exceptions from organizational norms to achieve career aspirations. "Shaping" involved proposals for individual advancement that would alter organizational norms. 


\section{Findings}

When prompted for a self-advocacy example, $85 \%$ of the men and $95 \%$ of the women were readily able to recall a recent example. Men and women reported the same frequency of career negotiations (median $=3$ "once a quarter," IQR $=2-3$ "once a month" to "once a quarter"). In contrast to the typical negotiation simulations, $83 \%$ of the negotiations lasted multiple days (median $=25$ days, $\mathrm{IQR}=2.5-120)$ and tended to involve multiple parties.

We coded separately for negotiating subjects and strategies, and then tried to gain insights from overlaying the two sets of codes, as illustrated in Figure 1a. Table 2 presents a summary explanation of the asking, bending, and shaping codes with representative quotes and illustrative examples of the three primary subject categories (role, work-family, compensation). The executives recounted role-related examples of asking, bending, and shaping. All of the work-family and compensation negotiations involved bending. Two patterns emerged that we sought to explore more deeply, one general and one gendered.

General pattern: Asking, bending, and shaping for role advancement. The first striking pattern in the career-negotiation accounts was the preponderance of role-related negotiations ( $96 \%$ of men's, $85 \%$ of women's). Only one man and one woman recounted examples of compensation negotiations. Fourteen percent of the women's negotiation examples, and none of the men's, centered on work-family conflicts. Next, we describe distinctions we observed among the asking, bending, and shaping strategies by comparing sample role negotiations.

As introduced above, the asking code captured career-related requests or proposals that are routinely resolved through negotiation between the employee and employer. The following is a representative quote from a government executive describing a role-related asking negotiation:

"My negotiations really revolved around what I believed would be effective development for myself and what my leaders ... believed would be effective development for me. So really, it was the negotiation around where I went to do developmental assignments, how long I went to do them, what types of functions I would do for them." (G25) 
The interviewee explained that such negotiations are standard: "those [developmental assignments] you have a tremendous amount of latitude to negotiate" (G25).

Asking is, in essence, a form of "organizational routine" (Feldman \& Pentland, 2003) in which there is a formally or informally recognized menu of career-related issues and options to negotiate. The routine character of asking negotiations allows for a familiar "dance of negotiation" (i.e., an exchange of value-claiming and value-creating offers) between manager and employee (Lax \& Sebenius, 1986). Confidence that the executives knew the dance of negotiation seemed to explain the overwhelming positivity of the asking examples (median $=5$ on five-point scale). The following quote from the case example above is illustrative:

"[I say] 'positive' because the process itself felt like a fair negotiation... I felt like I would be listened to. I felt like there would be concession on both sides. ... So, if it was not something I wanted to do, but my stakeholders thought it ... was a good thing because there was some development for me, ... I believed it would be best for me even if [the outcome] was not what I thought going in." (G25)

Conversely, the most negatively rated asking example was distinguished by a lack of clarity:

"I'm not necessarily looking at this as...me being entitled..., but I also don't want to...be taken advantage of... I'm just not sure what their thought process is... We've had conversations, but I'm still in kind of a question mark as far as the direction going forward." (G48)

This interviewee was a minority man who had presented to his manager cases of others with equivalent or less experience who were granted the opportunity he was requesting. This case may be illustrative of a growing body of experimental evidence that minority men, as well as women, have a harder time making standard asks than majority men (Al Dabbagh, Bowles, \& Thomason, 2016; Artz, Goodall, \& Oswald, 2018; Hernandez, Avery, Volpone, \& Kaiser, 2018).

In contrast to asking, bending involved exceptional arrangements that deviated from standard practice. Therefore, bending appears most likely to occur in the absence of an opportunity to "ask" (i.e., there is no established policy, practice, or precedent for meeting one's aspirations) or when asking is unsuccessful (i.e., one's aspirations cannot be met within the 
standard menu of negotiable issues and options). The following is a quote from a bending negotiation. As in the previous asking example, the executive initiated an asking negotiation over a developmental work detail. However, she could not achieve her aspirations through the standard dance of negotiation between manager and employee:

"Everyone [at my level] is required to do 120-day detail at an [executive] level position. ... My boss's boss ... wanted me to come down to his office ... and work on ... something that I have done a lot of in my career. ... I had heard that there was going to be a task force..., and that's what I wanted to do. ... But he then countered with another project in [his department]. So, he was really trying to keep me ... working on things that would benefit him, and I was looking for growth experiences."

Rather than accept an unsatisfactory outcome, the executive sought an unconventional solution. She worked with her direct supervisor to build a coalition of support for her to join the task. force. She explained, "it probably took a month and a half," including getting "a directive from the undersecretary" and "some politicking with the boss's boss." The conflict was finally resolved with a proposal for her to support her home department while serving on the task force:

"I said that I would be willing to help [his department] on the side, but that I did not want to do that as a full-time, 120-day development assignment. ... He said, 'Well, you can go...,' and I held true to my word and did both jobs." (G55)

The executive expressed satisfaction with the way she had handled a tough negotiation — "I didn't waffle or waver" - and with the support she received from senior colleagues, but she also acknowledged the risks of stretching the system to achieve her career aspirations: "I was really worried about whether there'd be any reprisal." Ultimately, she believed her strong work reputation and performance, as well as the good press she received for her agency, resolved lingering concerns. This idea that her status as a valued employee gave her extra allowance to deviate from organizational norms aligns with the literature on idiosyncratic work arrangements to recruit and retain distinctively valued employees (Miner, 1987; Rousseau et al., 2006).

Rousseau and colleagues' definition of i-deals has commonalities with our "bending" code (viz., individual negotiation of nonstandard work arrangements), but the "i-deal" is a 
broader concept in which nonstandard refers to the heterogeneity of work arrangements. For instance, Hornung and Rousseau (2008) studied a flexible work policy as a form of i-deal because only a fraction of employees made use of it. We would code such a negotiation as “asking" because it involved accessing an existing organizational policy. An employee who negotiated a work arrangement absent or deviating from policy or precedent would be "bending."

As explored in greater depth below, women tended to recount more positive bending experiences than men (male median $=3, \mathrm{IQR}=2-4$; female median $=5, \mathrm{IQR}=3-5$ on five-point positivity scale). Women also recounted a broader range of bending examples. Similar to the example above, most of men's bending examples were stories of working around unsupportive colleagues or superiors to find unconventional solutions to unsatisfactory asking negotiations.

Shaping involved making proposals for individual career advancement that would intentionally alter organizational structures or practices. Rather than drawing from an existing menu of employment issues and options (asking) or attempting to negotiate an individual exception to organizational norms (bending), those making shaping proposals laid out a case for organizational change. Bending negotiations might set the precedent for changes in organizational practices, but they are framed narrowly in terms of individual accommodations.

The following is a shaping example in which the executive negotiated for an elevation and expansion of his role in a way that would "change the way we do business":

"I negotiated and my boss agreed that ... we would ... look at all of our administrative functions across the board, which was a major undertaking. ... So we had to change the way we do business ... [to] not only include the [one] function but include the leadership from the various program [heads] as well as the [unit] executives, because the need for ownership in this program was going to be significant." (G70)

He continued on to explain that he made the case for this expansion in his individual scope of authority in terms of the strategic interests of his organization:

"The arguments I made had to do with, on the horizon, it was evident that the agency was in trouble with its financial health. ... 'If we don't get our house in order..., they will do 
it for us.' ... 'Rather than have something forced upon us, we would be in a better place to kind of be in control of our own destiny — craft what that looks like." (G70)

The shaping quote in Table 2 also illustrates this strategy of making a proposal for individual career advancement that would change organizational practices for strategic purposes.

As compared to asking or bending for opportunities for role advancement, role shaping negotiations were more transparently about "claiming leadership" (i.e., a process of social influence that leads to mutual recognition of a leader-follower relationship within the organization, following Derue \& Ashford, 2010). As would be expected of a negotiating strategy that required garnering support for organizational change, the reported length of shaping negotiations was substantially longer than the individually focused asking or bending negotiations. Shaping negotiations reportedly ranged from two months to a year and a half (median $=113$ days, IQR $=70-365)$, whereas asking and bending negotiations tended to take a few weeks (asking median $=21$ days, $\mathrm{IQR}=1-60$; bending median $=16$ days, IQR $=3-90$ ).

Gendered pattern: Why would women rely on bending more than men? It was predictable that women would report more work-family negotiations than men, but initially counterintuitive that women would report more bending than men. As depicted in Figure 1b, the distribution of men's negotiations by strategy fit with what one might expect a priori: standard negotiations as most common (asking), followed by attempts to gain personal exceptions (bending), and then bids to play a role in organizational change (shaping). In contrast, women's modal negotiating strategy was bending, following by asking and then shaping.

After overlaying our codes of what and how the executives negotiated, women's reliance on bending strategies seemed partly explained by the salience of work-life conflicts in women's career negotiation accounts. All work-family negotiations involved bending. The following quote is representative of bending to resolve work-life conflicts (see also Table 2):

"I was successful in getting my duty station changed. I literally am the one person from 
this office who sits in [state] now, and I still report directly to the manager. My title changed. ... I still perform a lot of the same substantive functions, but I was able to keep my pay grade, stay with the office, and keep doing the work I liked, and ... be able to find the time to take care of my father." (G40)

This example is characteristic of bending, as opposed to shaping, because the executive pursued a personal accommodation rather than a change in organizational practices or structures.

There was one other type of role-bending negotiation that only women recounted, which involved negotiating for assignments for which they were nontraditional candidates (e.g., women ascending male-dominated hierarchies with atypical professional backgrounds). In one case, an executive explained that there was a position for which she and others thought she was a strong candidate, but she fell out of consideration because she lacked a particular technical certification: “He wouldn’t even look at my résumé. All he would say is, 'Is she [technically] certified?"” (G58). She explained how personnel systems impeded lateral movement:

"Well, you can't ever get to [that level of technical] certification in any field other than the one you grew up in because it requires experience. So, although I had all the training, I had all the education, and I had [relevant] experience..., I had not [performed that function]. So, I couldn't get [a higher level] certification. So, he just looked at that and said, 'Nope... It's not going to happen"” (G58).

As she negotiated, she had to persuade decision makers that "they could take a risk [and] that the [relevant] experience that I had...would make me an effective leader at the senior level" (G58).

Our inductive analysis led us to the preliminary proposition that women may use bending strategies more often than men to cope with experiences of organizational "lack of fit" (Heilman, 1983). In particular, bending may be a tool for overcoming at least two well-documented barriers to women's career advancement: work-family conflicts and lack of traditional professional qualifications for counterstereotypical roles (Goldin, 2006). In organizational contexts in which advancement processes are implicitly structured on a masculine-stereotypical model, women more often than men may need to employ their negotiating competences to break new paths.

While the women characterized their bending negotiations in largely positive terms, the 
findings still raised questions for us about the potential costs of bending strategies for women's career advancement. For instance, might bending to resolve work-family conflicts raise questions about women's professional potential (Leslie, Manchester, Park, \& Mehng, 2012; Rousseau et al., 2006)? Could women be investing more time and social capital in other career-advancing activities if they did not need to be bending masculine-stereotypic "ideal worker" norms (Acker, 1990)? Women in this sample told proportionally fewer shaping stories than men, and shaping was the strategy most clearly associated with claiming leadership (Derue \& Ashford, 2010).

\section{Discussion}

The purpose of Study 1 was to develop an organizationally grounded perspective on the role of negotiation in managerial career advancement, starting with interviews of male and female government executives in the process of rising to the highest levels of the U.S. civil service. These executives' accounts of their career negotiations depict both men and women engaging in a broad range of career negotiations, predominately over their role development (see Figure 1a). Looking forward, we aimed to test whether characteristics of this study context might have colored our findings. Would our emergent constructs (e.g., bending, shaping) have validity outside of the highly bureaucratized employment context of the U.S. federal government? Did role negotiations dominate because other terms of employment are less negotiable in the public sector? In Study 2, we tested our constructs in a private-sector, corporate context.

\section{STUDY 2}

In Study 2, we surveyed female and male partners in a large professional services firm about their career negotiations. We recruited partners who did and did not hold leadership positions (e.g., heading regions or markets) to see if holding a leadership role altered what or how they negotiated. We asked the partners how frequently they engaged in role, workload, and compensation negotiations and about their propensity to use asking, bending, and shaping 
strategies. We also asked them to describe a recent career negotiation and coded their examples.

Based on our literature review and findings from Study 1, we expected to observe gender effects on what male and female executives negotiated-specifically, that women would report more workload negotiations than men and men more compensation negotiations than women. Based on our Study 1 results, we also predicted that women would report more bending in than men and that, overall, partners in leadership roles (versus not) would report more shaping.

\section{Data Collection}

Participants. Participants were partners in two divisions of the U.S. offices of a global professional services firm. There was no effect of division, so we combined the samples. We developed the survey in consultation with a human resources executive and pretested questions with seven other executives in the firm. The firm distributed the survey to a random selection of partners in four equally balanced categories: 2 (years in partnership: $<8,>8) \times 2$ (gender: male, female). The response rate was $29 \%$ for male partners and $37 \%$ for female partners. We removed two cases due to missing data, leaving a final sample of 67 men and 89 women.

We can only speculate as to why women responded to the survey at a higher rate than men. A female executive distributed the survey, and it was sent to a higher proportion of female than male partners to allow for a gender-balanced sample. Assuming there is some homophily in the partners' social networks (Ibarra, 1993), female partners might have been more aware of and receptive to the survey. In any case, we still obtained a fairly balanced sample. The male (as compared to female) respondents were only slightly more likely to hold a leadership position in the partnership (37\% of men, $26 \%$ of women, $\left.\chi^{2}[1, \mathrm{n}=156]=2.36, p=.12\right)$. There were no gender differences in years of work experience (male median $=22, \mathrm{IQR}=19-26$; female median $=21, \mathrm{IQR}=18-26)$. Men had slightly more years in the partnership (male median $=9, \mathrm{IQR}=4-$ 16; female median =8, IQR 3-14). Those holding leadership positions (versus not) had, on 
average, five more years of experience and six more years in the partnership. Men were more likely to be primary breadwinners ( $82 \%$ of men, $55 \%$ of women reported contributing $81-100 \%$ of household earnings) and to have infant or school-age children ( $75 \%$ of men, $58 \%$ of women).

Survey. The survey opened with an explanation that its purpose was "to learn about career-related negotiations within [the firm]." We defined career-related negotiations as "careerrelated conversations and requests that involve some problem-solving, creative options, tradeoffs, or a conflict to be resolved with [firm] colleagues." We illustrated this definition with examples of formal (e.g., job offer) and informal career-related negotiations over topics such as client assignments, leadership roles, developmental opportunities, and workload. Finally, we clarified that informal negotiations include "short one-on-one conversations" as well as "conversations with multiple colleagues over weeks or months" that "are about navigating your career in ways that work for you, your colleagues, and the firm."

The first set of questions related to their experiences negotiating job offers, client assignments, leadership roles, professional development, and workload. Then we asked the partners to briefly describe "in 1-2 sentences" a specific career-related negotiation example and to answer follow-up questions about it. The survey concluded with demographic items, including whether they held a leadership role in the partnership and about aspects of their personal background (i.e., gender, years of experience, contribution to household income, etc.). We did not collect data on race or ethnicity because it could be identifying alongside the other data.

Measures. We based our survey measures on the primary subject codes (role, workfamily, compensation) and strategy codes (asking, bending, shaping) developed in Study 1 and adapted them following pretesting. We inquired about the frequency with which the partners engaged in three types of role negotiations: client work, developmental opportunities, and leadership roles. During pretesting, executives shared vivid, firm-specific examples of these 
three types of role negotiations, and what we meant by "role negotiations" seemed to make more sense with specific examples. These distinctions also enabled us to test for gender differences in types of role negotiations. To reduce the potential for gender-congruent responses, we surveyed the executives about how often they had engaged in negotiations over "workload (e.g., scope of work, number of projects, work hours, travel, flexible hours or work space)" as opposed to "work-family conflicts" and about how often they negotiated their "job offer (e.g., salary, benefits, title, etc.)" as opposed to "compensation" (see Supplemental Materials).

To measure the propensity to engage in asking, bending, or shaping negotiations, we created two-item scales indicative of each of these negotiating strategies. The asking items related to making standard requests, the bending items to making exceptional personal requests, and the shaping items to making strategic proposals for a new leadership role (see Supplemental Materials). The items in each scale were highly correlated: asking $r=.77$, bending $r=.75$, shaping $r=.65$. The three scales were moderately correlated, with $r$ s ranging from .18 to .27 .

Confirmatory factor analysis supported our conceptualization of asking, bending, and shaping as distinct constructs. Principal components factor analysis of the six items produced three factors with eigenvalues greater than one. The rotated factor loadings cleanly separated the three constructs. The first factor had loadings of .92 and .93 on the asking items and loadings less than .17 on the bending and shaping items. The second factor had loadings of .93 on the bending items and loadings less than .13 on the asking and shaping items. The third factor had loadings of .89 and .91 on the shaping items and loadings less than .18 on the asking and bending items.

We coded the career negotiation examples only by primary subject because the short descriptions were too spare to code for negotiating strategy. Two authors blind to gender and leadership role sorted each example by role, work-family, or compensation with an agreement rate of $94 \%$. Any ambiguities were resolved through discussion. Lacking details, we designated 
two cases as "unclear." The follow-up questions asked respondents to list up to three people with whom they had negotiated and to report whether they were the same gender as the respondent. We inquired how long the negotiation lasted (days), whether it was resolved, and how satisfied they felt with the outcome and process (7-point scale: $1=$ Strongly disagree, $7=$ Strongly agree)

\section{Findings}

We first report our analyses of the negotiation examples. Table 3 presents descriptive statistics for scale-based survey items. The responses to the survey items were not normally distributed, so we report medians and Spearman's rank correlation coefficients. We report tests by partner gender or leadership role using Wilcoxon rank-sum (Mann-Whitney) z-statistics.

Career negotiation examples. Sixty-three percent of respondents described a specific recent career negotiation ( $56 \%$ of men, $67 \%$ of women), $20 \%$ reported that they could not think of an example, and 17\% declined to respond. Eighty-eight percent of negotiations were resolved, and most felt satisfied with the outcome (median $=6, \mathrm{IQR}=5-7)$ and process (median $=5, \mathrm{IQR}$ 3-6). As in Study 1, negotiations occurred over extended periods of time with multiple negotiating counterparts. The median negotiation lasted 90 days $(I Q R=30-180)$. Seventy percent of the examples involved career negotiations with at least three counterparts; $13 \%$ involved one counterpart. Reflecting the male-dominated work environment, $90 \%$ of men's negotiating counterparts were men, whereas only $13 \%$ of women's counterparts were women.

Gender moderated the pattern of what partners reported negotiating $\left(\chi^{2}[4, N=98]=\right.$ $11.79, p=.02)$. As in Study 1, role negotiations predominated (87\% of men's, $78 \%$ of women's examples). Women reported more examples of work-family conflicts (19\% of women's, none of men's). Men reported more compensation negotiations (13\% of men's, 3\% of women's).

Frequency of role, workload, and job-offer negotiations. The partners reported how frequently they had negotiated their role, workload, or job offers on four-point scales (i.e., $1=$ 
never, 2 = once, $3=$ a few times, $4=$ several times). Table 3 reports descriptive statistics on overall frequencies. There were no gender differences in the frequencies of role negotiations (zs $<|0.85|, p s>.39)$. Most reported negotiating their roles at least "a few times": $76 \%$ for client assignments, $66 \%$ for developmental opportunities, $69 \%$ for leadership roles. There were gender differences in the frequency of workload and job-offer negotiations. Women reported a higher frequency of workload negotiations than men (female median $=3$, IQR 3-4; male median $=3$, IQR, 2-4; $z=-2.34, p<.02$ ). Men reported a higher frequency of job-offer negotiations than women (female median =2, IQR 1-3; male median $=2$, IQR, 2-3; $z=2.66, p<.01$ ).

Propensity to ask, bend, and shape. Figure $1 \mathrm{~b}$ displays the partners' median responses to the asking, bending, and shaping scales. There were no significant gender differences in partners' tendency to agree that they used asking strategies $(z=-0.10, p=.92$; overall median $=5$, IQR $=$ 4-6) or shaping strategies $(z=0.04, p=.97$; overall median $=6$, IQR 5-6.5). However, replicating the results of Study 1, women reported a stronger propensity to use bending strategies $(z=-3.23, p=.001 ;$ female median $=4, \mathrm{IQR}=2-5.5 ;$ male median $=2.5, \mathrm{IQR}=1.5-4) . \mathrm{We}$ conducted an ologit regression to test whether this gender effect would hold controlling for breadwinner status and frequency of workload negotiations. Controlling for breadwinner $(\mathrm{B}=$ $.43, S E=.31, p=.16)$ and for workload negotiations $(\mathrm{B}=.56, S E=.15, p<.001)$, being female remained positively associated with a propensity for bending $(\mathrm{B}=.68, S E=.30, p<.03)$.

As in Study 1, shaping was associated with evidence of leadership claiming. Partners who held leadership positions (versus not) agreed more strongly that they had used shaping strategies in their career negotiations $(z=-3.35, p<.001)$. As shown in Table 3 , shaping was also significantly correlated with negotiations for leadership roles $(\rho=.46)$.

\section{Discussion}


In Study 2, as in Study 1, men and women were equally able to recall recent careerrelated negotiations, and role negotiations predominated. We gained further conceptual support for the asking, bending, and shaping constructs developed in Study 1. Factor analyses of our scale items confirmed we were measuring three distinct constructs. As illustrated in Figures 1a and $1 \mathrm{~b}$, we replicated our finding from Study 1 that female (as compared to male) executives report a greater propensity for bending. In both studies, this gender difference in bending was partly, but not fully, explained by gender differences in the frequency of workload negotiations. Again, shaping strategies were associated with the pursuit and attainment of leadership roles.

\section{STUDY 3}

In Study 3, we transitioned to studying executive women's accounts of career negotiations in the context of their career trajectories. We analyzed data from the career stories of executive women in large and high-growth enterprises. We aimed to gain insight into how the women had used asking, bending, and shaping strategies to attain their leadership positions.

\section{Data Collection}

We reanalyzed the raw data from an interview study conducted on how women explain their ascent to counterstereotypical leadership positions (Bowles, 2012). Out of 50 interviewees, half held senior leadership positions in major corporations and half in high-growth ventures. One third were identified through two university leadership boards and the rest from public lists recognizing corporate and entrepreneurial leaders. The executives held positions in wide-ranging industries, including consumer products, financial and other professional services, media, petrochemicals, retail, and technology. Table 1 displays descriptive statistics. The semistructured interview protocol focused on pivotal points in the executives' career trajectories. The interviews ranged from 45-150 minutes and were audio-recorded and transcribed.

\section{Data Analysis}


We searched the interviews for examples of career negotiations in organizational contexts. As in Study 1, at least two authors reviewed each example to confirm that it involved career self-advocacy and an explicit negotiation. We excluded cases in which an entrepreneur's career self-advocacy and advocacy for her organization were confounded. This led to a database of 64 career negotiations, which we coded using the same procedure as in Study 1. We analyzed the cases for insights into how the negotiations contributed to executives' career advancement.

\section{Findings}

Career negotiation subjects and strategies. As in Studies 1 and 2, role negotiations predominated. More than three-quarters $(78 \%)$ of the career negotiation examples related to role advancement, including asking (42\%), bending (26\%), and shaping (32\%) strategies. The remainder of the negotiation examples were evenly divided between work-family and compensation. As observed in Study 1, work-family negotiations tended to involve bending (86\% bending, 14\% asking). Compensation negotiations mostly involved asking (86\% asking, $14 \%$ bending). We focused our inductive analysis on the relatively understudied processes of role and work-family negotiations (Edmondson \& McManus, 2007). Iterating between the data and literature, we focused on three functions of career negotiations: navigating institutionalized career paths, overcoming barriers, and claiming leadership.

Navigating institutionalized career paths. The women offered numerous examples of employing negotiation as a tool for navigating institutionalized career paths in organizations (i.e., recognized scripts of career advancement in organizations or industries, Barley, 1989). Many of these involved asking negotiations in which the woman self-advocated during routine role negotiations between manager and employee. The following is a representative example:

"I had been approached by the company and asked, 'Did I want to run a [region] or did I want to go up the next level in [function]?' I said, 'I wanted to run a [region].' [But], my boss came back to me, and he says, 'The company needs you to do the next level of [function].' So I said, 'OK. But after this, I want to run a business.'” (C1) 
In multiple accounts, the women described their no-agreement alternatives if they could not reach a mutually beneficial solution in these routine role negotiations (e.g., "If they... felt I didn't have the potential to run a business, then I would...pursue opportunities elsewhere" [C1]).

Surmounting traditional barriers to women's career advancement. When we reviewed examples of negotiation accounts in which the women had surmounted traditional barriers to women's career advancement (e.g., work-family conflicts, lack of traditional qualifications for counterstereotypical roles, perceived discrimination), we observed — as in Study 1 -a preponderance of bending. In Table 2 and below, we present illustrative examples of successful bending negotiations related to work-family conflict and role advancement.

Among the work-family negotiations, we observed a variety of distributive (i.e., zero sum) and integrative (i.e., "win-win”) approaches. Table 2 (under Study 3) displays a workfamily bending example of how an executive described in distributive terms her refusal to accept her company's proposal that she enter an elite full-time MBA program in another city. The following is an example of a dual-career conflict negotiated in more integrative terms:

"I just went through all the stages of account management... and then I raised my hand because I felt I was ready to run a unit. ... Usually the way you do that is you move to another place where there is a smaller operation, because [my city has] the largest operation of all. So, you would move ... and run that first to give you the experience of running an organization. But because [of my husband's career], I couldn't do that. [He] couldn't just pick up and go to [another city] for two or three years. And, so, I raised my hand and said, 'You know what, I'd actually like to run [Agency X], which was in [my city], but was smaller and would give me a different experience." (C22)

We coded this as bending because her proposal violated norms of career progression for someone with her potential. She explained that, "Frankly, they were startled" because:

"I was probably the only person who ever volunteered to go from [Agency $\mathrm{Y}$ to $\mathrm{X}$ ], because usually you were put out to pasture in [Agency X]. And there were people who said to me, 'How could you do this? You're sacrificing your career. You're going to go into a dead end.' And I never really saw it that way at all."

She perceived a win-win opportunity to meet family constraints and demonstrate her leadership 
potential by turning around an undervalued business unit - and she succeeded. She eventually led the entire company and recounted this negotiation as pivotal to her advancement.

There were numerous examples of women negotiating for roles for which they lacked traditional qualifications (e.g., "He said, 'It's a joke. You haven't worked a day in your life at this."” [E5]). Following is one such example in which the woman negotiated a leadership role.

"I went to the vice chairman ... I said, 'I can do this...' He said, '...do you know how many people have... told me they could succeed at this and then fallen on their faces and squandered the [company's] money? I said, 'It won't happen.' ... He actually overrode the $\mathrm{CIO}, \ldots$ and the CIO immediately opened a search to replace me because I had no systems background. But, ... I was able to prove ... within six months that I was great at this. I knew how to pick great people and I was a strong leader... and I was actually quite technically competent. You can learn what you need to learn." (C8)

Other stories (e.g., Table 2, third bending quote for Study 3) described how women negotiated, not only for access to counterstereotypical roles, but also for extra support to succeed in them.

As observed in Study 1, while bending helped women overcome their lack of fit with traditional masculine-gendered norms of career progression, bending also came with risks. The interviewee who negotiated an exception to pursuing an MBA said she feared her refusal would be a "show stopper." As reflected in the following quote, interviewees also described the courage it took to assume leadership roles for which they were not traditionally qualified:

"I'm not a [technical expert]. I've worked in [this field] for the last eight years and most of that was in [administrative functions]. ... I do have to rely more heavily than what is comfortable for me on my technical people... It takes a lot of self-confidence and bravery to go out there and know that you don't know." (C9)

While projecting confidence in the face of uncertainty is common to male and female leaders, perceived failure in counterstereotypical roles weighs more negatively on one's perceived competence than failure in stereotype-congruent roles (Brescoll, Dawson, \& Uhlmann, 2010).

Claiming leadership. Building upon our findings in Studies 1 and 2, the shaping examples in Study 3 further enriched our understanding of shaping as a process of leadership claiming (Derue \& Ashford, 2010). As described in Study 1, a differentiating characteristic of 
shaping negotiations (as compared to asking or bending) was that the negotiator was making a proposal for individual career advancement that would involving changing organizational structures or practices. Congruently, shaping negotiations tended to involve galvanizing organizational partners in support of organizational change. In asking and bending negotiations, it behooves the negotiator to explain why what she is proposing is also good for the organization (e.g., role asking quote in Table 2 under Study 3) (see also Bowles \& Babcock, 2013). However, demonstrating mutual benefit in a shaping negotiation also requires persuading others of the strategic benefits of the proposed organizational change. The following example is illustrative:

"I had an idea to take what I was doing... and really make it big and really turn it into a business for [the company]. ... I went to [CFO] and said, 'If you want to keep [your corporate vision], then you need to have this special program that's in my head. Let me tell you about it...' [The CFO] let me do a little pilot... I said, 'Give me a few months and let me show you...' It was extremely successful. ... [After that,] I approached our CFO and I shared my whole idea... He said, 'All right. This sounds great, but it has to be great from a business perspective as well.' He said, 'You call me when the business plan is ready... I will get you the appropriate audience, and, if it makes business sense, then we'll do it.' ... When I did my business plan, part of the plan was that this would become this corporate program and I would be the person who would run it... I just had this thing, 'I've been playing around here in sales... and this isn't really what I got my MBA for.' I wanted to do more... 'By God, I'm just going to go for it. I'm going to tell them part of the plan is they make me an officer of the company...' And they did!"' (C18)

Through a multi-round negotiation with key stakeholders, she persuaded senior executives that her strategic proposal aligned with the company's vision and financial interests and that she was the person to lead the creation of a new business line. Table 2 (under Study 3 ) displays another shaping example involving negotiations with organizational stakeholders to back the woman's strategic vision for a new leadership role and change in organizational structures and practices.

\section{Discussion}

As in Studies 1 and 2, we observed a range of asking, bending, and shaping accounts, primarily involving role advancement. We found additional support for the proposition that women use bending to cope with their "lack of fit" (Heilman, 1983) with traditionally masculine- 
stereotype career paths. This study also further illuminated shaping as a form of leadership claiming (Derue \& Ashford, 2010). In Study 1, men reported more shaping negotiations than women. In Study 2, a propensity for shaping was unrelated to gender. The findings of Study 2 and prevalence of shaping examples in Study 3 suggest that shaping contributes to women's and men's leadership advancement. Indeed, shaping may be a particularly gender-congruent form of leadership claiming for women because it involves making a mutually beneficial, as opposed to competitive, case to expand one's authority (Bowles \& Babcock, 2013).

\section{STUDY 4}

In Study 4, we used the same research method as in Study 3 to analyze the career stories of women in executive and non-executive management positions in predominately Muslim countries in the Middle East and North Africa (MENA). In addition to enabling comparative analysis of the career negotiations of women in the top and middle rungs of organizational ladders, this sample allowed us to stretch us beyond the "WEIRD" (i.e., white, educated, industrialized, rich, and democratic) samples (Henrich, Heine, \& Norenzayan, 2010; Jones, 2010) that dominate research on gender in negotiation and women's leadership advancement. The interviewees were highly educated and employed in industrialized sectors of their emerging economies, so had much in common with the informants in our first three studies. However, they were advancing their careers in a more strictly and explicitly gendered social context, in which women are expected to devote themselves to home and family and men to breadwinning and leadership in the public sphere (e.g., see Moghadam, 2004). Despite making dramatic strides in women's access to higher education, MENA is one of the most challenging regions in the world for advancing gender equality in work (Hausmann \& Tyson, 2013).

\section{Data Collection}

The sample included interviews with 45 executive and non-executive women from a 
range of government, corporate, and entrepreneurial ventures in financial and other professional services, retail, technology, and tourism. Table 1 displays descriptive statistics. The executives were recruited from public lists and awards recognizing corporate and entrepreneurial leaders and the non-executive participants through informants in the region. The semi-structured interview protocol inquired about their career trajectories and how they balanced personal and professional roles. The interviews lasted 60-90 minutes and were audio-recorded and transcribed.

\section{Data Analysis}

We identified and coded career negotiation examples as we had done in Study 3. We then analyzed the 35 negotiation examples identified (12 non-executive, 23 executive) with attention to comparing and contrasting the accounts of executive and non-executive women.

Career negotiation subjects and strategies. As in Studies 1, 2, and 3, role negotiations predominated. Overall, $85 \%$ of the career negotiation examples related to role advancement, involving a range of asking (37\%), bending (23\%), and shaping (40\%) strategies. Eleven percent of the examples related to resolving work-family conflict, all of which involved bending. There was only one compensation negotiation that we coded as asking.

Comparing executive and non-executive career-negotiation accounts. As illustrated in

Figure 1c, the executives and non-executives recounted contrasting patterns of negotiation strategies and subjects. Consistent with our conceptualization of shaping as a form of leadership claiming, examples of shaping were the exception for non-executives and the mode for executives. The following quote is representative of an executive shaping example:

"I said, 'OK, listen... You want to stay exactly where you are forever,... but this doesn't work if you want to retain people like me.' ... That was the proposition... You can... stay around the small amount of business that you do annually, ... or you can decide to become a $\$ 10$ million business... I had been talking about this for two, three years before... I said, 'I can't keep going back-and-forth. I'm leaving...' They called me and said, 'No, no, no. Tell us exactly what you want.' I sat down with the founding partner and the other partner that I was proposing becomes managing partner..., and we charted this out. He said, 'Okay... You've set up the initial restructuring scheme. Let's put details 
on it...' I said, 'Okay, in that case, I'll stay.'” (E10)

As in previous shaping examples in Studies 1 and 3, the shaping negotiations were inherently multi-party, requiring engagement of a winning coalition of key organizational stakeholders.

There was one shaping negotiation in the non-executive sample of career stories, which distinguished itself only in the scope of the leadership claim. The woman explained:

"I said, 'I have my initiative.' They are all employees of the bank, ... same [mid-level] as I am. ... So, I went to them, 'I have this initiative. It's an initiative ... to empower women and improve their bankability...' And they agreed to support me." (N5)

She was not making a claim to a higher position of authority, but to a mutually recognized leadership role in creating a novel set of institutional practices and services.

There was also a conspicuous difference in the substance of the bending examples recounted by executive and non-executive interviewees. Bending examples shared by executives tended to relate to their roles, as in the following example:

"He offered me [a role in government].... I suffered at that time to take the decision because [my private practice was very successful]... I asked them to give me a [more prestigious title]. ... I was 36 . So, I asked for a [title typically granted to professionals] in the middle of their 40's... They gave it to me... They appointed me first to be the first female in [prestigious title]." (N9)

In contrast, more than half of non-executives' bending examples involved work-family conflicts.

In some cases, the strictly gendered social norms of the MENA region were transparent in the non-executives' stories of work-family conflict, as in the following quote:

"I'll never be the equal of a man here because of such detail like this: I cannot travel. I cannot be available at 7:00 in the morning. ... My boss calls the other guys at midnight when he has something very urgent; he would never do that with me." (N12)

However, in most examples, one could not easily identify from the story alone whether it was from the United States or MENA region. The following is an illustrative example in which a mid-level manager described coping with role demands from home and work:

"At a certain point in my career, I needed to cut down. I had kids. ... I couldn't work fulltime anymore.... [My area of work] is very demanding. ... If anything goes wrong ... on a weekend or in the middle of the night, ... it's an emergency... I decided I wanted to 
walk out of the [most demanding part of my work]. And I handed [it] over ... to a colleague... The biggest part of that decision was because I wanted to try to cut down on my working hours... [My husband] is out of the country all week long. So ... he can share very few responsibilities during the week - or none, to be more accurate." (N10)

Consistent with the literature on i-deals (Rousseau et al., 2006), she explained that her track record as a valued employee enabled her to negotiate a special part-time arrangement:

"I mean it wasn't easy to get... a part-time setup. ... None of my colleagues were able to get that setup. ... By the time I started to work part time, I had already been here for 12 , 13 years, and... gained the trust of the management in my capabilities." (N10)

While she still felt like a valued employee, it was apparent that she was making a tradeoff between professional advancement and care of family. All of the work-family negotiations described by the non-executive women had this distributive character.

\section{Discussion}

Study 4 made three primary contributions to our theory development. First, it provided further support for the proposition that shaping is a strategy women use to claim leadership. Second, it illustrated more clearly than Studies 1 and 3 the potential career tradeoffs in bending to resolve work-family conflicts. Third, it enhanced the potential to generalize our findings. In spite of the contrasting social contexts of women's career advancement in the U.S. and MENA regions, we observed more commonalities than differences in how and what women negotiated for career advancement. In Studies 5 and 6, we sharpened and tested the limits of our constructs (Eisenhardt, 1989). To reduce bias toward success cases, we sought examples of negotiation disappointments and successes. We increased the diversity of informants by recruiting participants from multiple global regions and at early as well more advanced career stages.

\section{STUDY 5}

In Study 5, we collected data from an international sample of female executives enrolled in a leadership training program. We asked them to recount briefly in writing recent examples of disappointing and successful career negotiations. We compared their accounts of success and 
disappointment, looking for contrasting patterns with the data collected in our first four studies.

\section{Data Collection}

Participants. Participants were 58 executives enrolled in a one-week women's leadership program. Table 1 lists sample titles and global regions represented. The women worked in 17 different countries and in a range of fields, including financial and other professional services, law enforcement, military and national security, and state and national politics. The response rate was $100 \%$ because the participants completed the survey as part of the educational experience.

Survey. Adapting the procedure used in Study 2, we asked participants, in counterbalanced order, to describe two experiences in which "you tried to negotiate something career-related for yourself": (1) "success case" (i.e., "you felt good about how the negotiation turned out") and (2) “disappointment case" (i.e., "you were not successful"). Participants coded the two examples by what (role, workload, job offer) and how (ask, bend, shape) they negotiated. To test whether our practice of sorting negotiations by primary subject (i.e., role, workload, job offer) obscured multi-issue negotiations, we asked them to "check all that apply." We described our asking, bending, and shaping codes in practical language and then asked them to choose which best described their negotiation. (See wording of items in Supplemental Materials.)

\section{Findings}

Recall rates. The recall rate of successful negotiations (90\%) was slightly higher than the recall rate of disappointing negotiations (79\%). Most successes occurred within the past year or so (77\% “within one year"; $21 \%$ "within past 2-3 years"). Disappointments reached slightly farther back (46\% "within one year"; 30\% "within past 2-3 years"; $24 \%$ more than 3 years).

What was negotiated. As in Studies 1-4, role was the most common subject negotiated. Respondents listed role as a subject in $72 \%$ of success cases and $61 \%$ of disappointment cases. About one quarter of all cases involved workload (26\% of success, $24 \%$ of disappointment) or 
job offer ( $30 \%$ of success, $28 \%$ of disappointment). Reinforcing our choice in Studies $1-4$ to code by a single primary subject of negotiation, the executives self-coded $75 \%$ of their success cases and $89 \%$ of the disappointment codes with a single primary subject of negotiation.

How negotiated. As illustrated in Figure 1d, the pattern of negotiating strategies used in the success and disappointment cases varied. The modal success example involving bending (49\%), followed by asking (34\%) and shaping (17\%). Among the disappointment cases, the modal strategy recounted was asking (57\%), followed by shaping (26\%) and bending (17\%).

As observed in our previous studies, successful bending cases overwhelmingly related to role and/or workload ( $93 \%$ of bending cases). As in Studies 1, 3, and 4, successful cases of bending included examples of negotiating access to work roles for which one was a nontraditional candidate (e.g., "I was sought out to take a management position, but in a field that is not part of my background" [P107]) and balancing work-family conflicts ("Transferring to a new position and location for one year that would support work life balance" [P109]). Successful job-offer negotiations were most often coded as asking (50\%) (e.g., "I negotiated a salary increase with my board... based on industry standards" [P127]).

Among the disappointment cases, asking negotiations tended to involve refusals by employers in routine role, workload, or job-offer conversations. For instance, one woman explained, "I have proven experience and expertise but was passed over" [P111]. Another reported, "My boss decided not to designate me...because ... the client preferred to be advised by a man" [P160]. Unfair treatment was a recurrent theme in the disappointment cases.

\section{Discussion}

The findings of Study 5 replicated and extended the results of our previous studies. As in Studies 1-4, most career negotiation examples related to role advancement. Similar to Study 1, the most common successful negotiating strategy described by women was bending (compare 
Figures 1a and 1d). However, when prompted for disappointing experiences, the women tended to describe unsuccessful asking negotiations. This contrasting pattern of successes and disappointments is intriguing. Recent field research suggests that women tend to be less successful in pay negotiations than men because their "asks" encounter more resistance (Artz et al., 2018). The case descriptions and pattern of results in Study 5 fit with the proposition that women face more challenges than men in their routine career negotiations.

\section{STUDY 6}

In Study 6, we conducted a more expansive survey of career negotiation successes and disappointments with a population of recent professional school graduates, including more explicit measures of their negotiation processes and perceived career gains from negotiation.

\section{Data Collection}

Participants. We surveyed 527 recent graduates (i.e., within three months to three years)

from a U.S. professional school. All had earned a certificate of distinction for their coursework in management and leadership. For completing the anonymized survey, respondents entered a lottery for a bag of insignia items and books. We obtained a response rate of $27 \%$, which was proportionately distributed by program, year of graduation, and gender (69 men, 71 women).

Survey. The survey was modeled on Study 5 with more items on process and outcome.

Measures. We used the same asking, bending, and shaping descriptions as in Study 5. We returned to coding one primary subject of negotiation, using the same descriptors of role and workload as in Study 5. To gain more insight into pay negotiations, we changed the "job offer" code to "compensation (e.g., salary, bonus, options, benefits, moving expenses)." After describing a success or disappointment, participants reported how long the negotiation lasted (days); with how many senior, peer, or junior counterparts they negotiated (4-point scale: $1=1$ person, $2=2-3$ people, $3=4-5$ people, $4=$ more than 5 people); how satisfied they were with the 
negotiation outcome and process (7-point scale: $1=$ Very unsatisfied, $7=$ Very satisfied); and to what extent the negotiation enhanced their leadership, authority, compensation, and work-life balance (5-point scale: $1=$ Not at all, $5=$ A great deal). (See items in Supplemental Materials.)

\section{Findings}

Comparing male and female respondents. The male and female respondents were professionally very similar. We observed no significant gender differences in age (median $=$ $33.5, \mathrm{IQR}=29-38.5$ ), years of work experience (median $=9.5, \mathrm{IQR}=5-15$ ), weekly work hours $($ median $=50, \mathrm{IQR}=40-52.5)$, annual compensation $($ median $=\$ 51 \mathrm{~K}-\$ 100 \mathrm{~K}, \mathrm{IQR}=\$ 51 \mathrm{~K}-$ $\$ 150 \mathrm{~K})$, percent contribution to household income (median $=61-80 \%, \mathrm{IQR}=41-100 \%)$, being from the United States (68\%), holding dual degrees (49\%), negotiation training (89\%), or career ambition (median $=4.6, \mathrm{IQR}=4.2-5$ on 5-point scale; 5-item scale adapted from Gray \& O’Brien, 2007). There were no significant gender differences in employment sector (44\% public, $25 \%$ private, $31 \%$ non-profit) or work field, which included consulting, economic development, finance, law, military, politics, social services, and technology.

More women than men reported few or no same-gender peers or superiors ( $51 \%$ women, $28 \%$ men). More men than women reported having children ( $18 \%$ women, $36 \%$ men). Men reported slightly more concern than women about home life interfering with work (male mean $=$ 2.54, $S D=0.83$; female mean $=2.26, S D=0.80 ; t[138]=2.05, p=.04)$; there was no gender difference in concern about work interfering with home life (overall mean $=3.15, S D=0.87$; $t[138]=0.22, p=.83)(5$-point single-item measures from Frone, Russell, \& Cooper, 1992).

As illustrated in Figure 1e, the only gender differences observed in the respondents' negotiation accounts related to the pattern of disappointment cases. There was no gender difference in the recall rate for successful negotiations (overall $81 \% ; \chi^{2}[1, N=140]=0.13, p=$ .72), but more women than men reported disappointments (female $76 \%$, male $59 \% ; \chi^{2}[1, N=$ 
$140]=4.44, p<.04)$. The reported pattern of women's disappointment cases replicated the pattern of disappointment cases reported by the female executives in Study 5. As in Study 5, asking was the most common strategy recounted in women's disappointment cases ( $46 \%$ asking, $28 \%$ bending, $26 \%$ shaping). In contrast, men's modal disappointment case involved bending (37\% asking, $49 \%$ bending, $15 \%$ shaping). Figure 1e shows this gender difference related primarily to disappointing pay negotiations. Among success cases, men and women reported a similar distribution of asking, bending, and shaping negotiations - primarily asking and bending about pay. This pattern contrasted with what we had observed in earlier studies.

Comparing success and disappointment cases. Most measures were not normally distributed, so we report medians in lieu of means. (See Supplemental Materials for descriptive statistics.) The recall rate for success cases (81\%) was slightly higher than for disappointments (68\%). As expected, satisfaction was higher in success than disappointment cases (outcome: success median $=6, \mathrm{IQR}=6-7$; disappoint median $=2, \mathrm{IQR} 1=3$; process success median $=6$, $\mathrm{IQR}=5-7$; disappoint median $=2, \mathrm{IQR}=1-3$ ). The recent graduates reported more pay negotiations than observed in earlier studies (success: 46\% pay, 39\% role, $15 \%$ workload; disappoint: $58 \%$ role, $36 \%$ pay, $6 \%$ workload). The median success case lasted two weeks as compared to a month for disappointments. For successes and disappointments, more than $95 \%$ of cases involved negotiating with more senior negotiating counterparts, about one quarter involved negotiations with peers, and a handful involved negotiating with more junior counterparts.

Comparing process and outcome measures by what and how negotiated. Among success cases, shaping took longer than bending, and bending longer than asking (ask median $=7$ days, bend median $=14$ days, shape median $=30$ days). The number of counterparts varied significantly by negotiating strategy $\left(\chi^{2}[8, N=114]=26.75, p=.001\right)$. Asking was typically a two-party negotiation ( $72 \%$ of cases involved one senior or peer). Bending and shaping 
negotiations usually involved multiple senior counterparts ( $70 \%$ of bending, $75 \%$ of shaping).

We used Wilcoxon rank-sum tests to compare perceived career gains by what and how respondents reported negotiating. For successful cases only, the primary subject of negotiation influenced the career gains reported. Successful role negotiations (as compared to workload and compensation) led to greater gains in leadership $(z=3.47, p<.001)$ and scope of authority $(z=$ $3.95, p<.001$ ). Successful compensation negotiations (as compared to role and workload) led to greater pay gains $(z=6.15, p<.001)$. Successful workload negotiations (as compared to role and compensation) led to greater work-life balance $(z=3.29, p=.001)$. Consistent with the findings in our earlier studies, leadership gains associated with successful shaping (median $=4$, IQR $=4$ 5) were significantly higher than those associated with bending (median $=4, \mathrm{IQR}=3-4, z=$ $2.92, p<.01$ ) or asking (median $=3, \mathrm{IQR}=2-4, z=3.65, p<.001$ ). There were no discernable patterns in the disappointment cases in terms of how the subject or strategy of negotiation influenced the process or perceived outcomes of negotiation.

\section{Discussion}

Study 6 helped to sharpen and test the boundaries of our constructs (Eisenhardt, 1989). In earlier studies, we found that female executives reported a greater propensity for bending than male executives. That finding was not replicated in this study of recent graduates. Given the repeated pattern of bending to resolve work-family conflicts found in Studies 1-5, differences in life stage and family status might help to explain why (see Table 1). The only gender difference observed in this study was in the pattern of disappointment of cases. Our findings from Study 5 and this study are consistent with recent field evidence showing that women encounter more resistance than men when "asking" for higher pay (Artz et al., 2018). The process measures in Study 6 reinforced our conceptualization of asking as a two-party "dance of negotiation" between manager and employee (Lax \& Sebenius, 1986) and of bending and shaping as more 
protracted, multi-party processes. As summarized in Figure 2, the outcome measures in Study 6 help to crystalize the differential career implications of what and how professionals negotiate.

\section{GENERAL DISCUSSION}

Currently, the dominant narrative of women's career negotiations in the academic literature and media is a deficit story about women's lack of assertiveness (as compared to men) in pay negotiations. To explore whether this account has overshadowed a richer, more nuanced story, we conducted an inductive study of women's lived experiences of career negotiations in organizations. With this set of studies, we aim to challenge scholars and encourage practitioners to develop new ways of seeing how women employ negotiation to navigate their career advancement, circumvent barriers, and claim leadership.

\section{Conceptual Framework for Expanding Research on Gender in Career Negotiations}

In Figure 2, we offer a conceptual framework for advancing the study of gender and negotiation in career advancement. The figure is structured around fundamental steps of a career negotiation, starting with one's ambitions, which inform more specific career aspirations related to one's role, pay, or workload. As noted above, we use the term career to refer to the progression of work-related experiences one has over one's life within and outside of organizational contexts (Arthur et al., 1989; Hall, 1972; Lyness \& Erkovan, 2016). Therefore, we include aspirations to manage one's workload to achieve caregiving as well as career ambitions (Bear, 2018). Given a specific aspiration, one has to decide whether to initiate negotiation and, if so, how. Based on our findings, we propose that, if successful, what and how one negotiates will influence one's negotiation outcomes and direct career gains.

In Figure 2, we use heavier shading and lines to indicate components of the conceptual framework that are already well-established in the literature. In terms of broader career ambitions and specific career goals, a great deal is known about how gender influences professional 
ambitions and gendered domestic roles, which lead men and women to make tradeoffs between compensation and work flexibility in paid labor (Goldin, 2014; Ridgeway, 2011). In terms of the decision to negotiate, there is evidence that prescriptive gender stereotypes inhibit women from engaging in pay negotiations (Amanatullah \& Morris, 2010; Bowles et al., 2007) and men from pursuing work flexibility (Berdahl \& Moon, 2013; Vandello et al., 2013) to avoid social backlash. There is also substantial evidence that gender influences negotiation outcomes (e.g., Artz et al., 2018; Mazei et al., 2015). There is relatively little research on how organizational contexts moderate gender effects in career negotiations. However, there is experimental and field evidence that ambiguity about negotiating norms inhibits women's propensity to negotiate for pay (Kray \& Gelfand, 2009; Leibbrandt \& List, 2014) and that ambiguity about standards for agreement increases the potential for gender differences in the outcomes of pay negotiations (Bowles et al., 2005; Mazei et al., 2015). As indicated by the thinner arrow stemming from organizational context, there is more work to be done to understand how organizational factors moderate gender effects on how men and women negotiate for career advancement.

Expanding research on what is negotiated. Below the steps in Figure 2, lighter boxes and lines indicate directions for future research based on our studies. Our findings suggest that pay negotiations represent only a narrow slice of career negotiations. Across five studies of executives' career negotiations, role negotiations predominated for men and women. The second most common topic for female managers and executives was workload, particularly to resolve work-family conflicts. Only recent graduates recounted a high frequency of pay negotiations.

The scope of our perspective on "what" men and women negotiate has important implications for how we understand negotiation as a micro-mechanism of gender inequality. Gender differences in the trajectories of men's and women's labor participation are the leading factors in explaining the contemporary gender pay gap (Blau \& Kahn, 2017; Goldin, 2006). In 
our studies, we observed numerous examples of how executive women employed negotiation strategies (viz., bending and shaping) to break into counterstereotypical career paths. Successful role negotiations that lead to gains in women's leadership and authority may do more to close the overall gender pay gap than compensation negotiations that increase pay in a current role.

In her Presidential Address to the American Economic Association, Claudia Goldin (2014) argued that "temporal flexibility" of paid labor is the final barrier to gender equality in economic opportunity. Temporal flexibility must be addressed as matter of organizational policy and culture (Kelly \& Kalev, 2006; Perlow \& Kelly, 2014), but its realization will hinge on individual negotiation processes. Particularly for managers and professionals, it is implausible that leaves of absence or flexible schedules could succeed without some interactive problemsolving involving trade-offs or conflict to be resolved (i.e., negotiation).

Future research should test longitudinal effects of workload negotiations on women's career trajectories and their potential to remain continuously employed. The bending accounts in Studies 3 and 4 suggested that distributive bargaining over work-family conflicts may be more stigmatizing and career limiting than integrative approaches. However, the potential for identifying integrative solutions hinges on contextual factors (Leslie, King, \& Clair, 2019). There might be more potential for integrative solutions in organizations willing to approach work-life balance as a question of work design (Perlow \& Kelly, 2014). The individual propensity to negotiate workload and the receptiveness of the organizational context may help to predict whether primary caregivers in dual-career partnerships remain engaged in paid work.

Expanding research on how men and women negotiate. From our inductive analyses, we developed three preliminary constructs—asking, bending, and shaping — related to how men and women negotiate for career advancement. We conceptualized "asking" as a negotiation process in which employees engage in routine negotiations - typically, a two-way conversation 
with an organizational superior - to chart their advancement along recognized career paths. This is the most commonly studied type of career negotiation, although almost always investigated in terms of formal negotiations of job terms at organizational entry or promotion. Our findings suggest that asking negotiations over role (e.g., work assignments, developmental opportunities) are probably more common in actual practice, particularly for rising professionals.

We observed suggestive evidence to support findings that women encounter more resistance than men in their asking negotiations (Artz et al., 2018). This may be because their requests are counterstereotypical within the organizational context (e.g., claim to levels of pay or authority traditionally associated with men). Future research should address the organizational conditions under which women have more difficulty succeeding in routine career negotiations.

We conceptualized "bending" as a strategy involving individual requests for exceptional work arrangements that violate organizational norms. Our findings suggest that bending is likely to require multiparty negotiations to build a consensus of organizational support to permit individual deviance. Bending strategies may be a solution when one's aspirations are blocked by conventional paths of career advancement. In Figure 2, we modeled bending as a strategy that one might choose directly or subsequent to a disappointing asking experience.

In Studies 1 and 2, we observed that women use bending more often than men. Data from Studies 1-5 indicated that women rely on bending to overcome their "lack of fit" (Heilman, 1983) with masculine-stereotypic organizational norms (Acker, 1990). We observed numerous examples across studies of women using bending strategies to manage work-family conflicts and to gain access to counterstereotypical roles. If women encounter more resistance than men in asking negotiations, that could be another reason for their greater reliance on bending.

In Through the Labyrinth, Eagly and Carli (2007: 65) argue, "The routes that women take to leadership in the workplace are not simple or direct but convoluted and frequently obstructed, 
especially for mothers." A propensity for bending may help to explain how women navigate nonlinear careers that stray from traditional paths (Mainiero \& Sullivan, 2005; Phillips \& Imhoff, 1997). However, as a form of organizational deviance, bending may be limited to highly valued employees and may create career risks as well as benefits (Rousseau et al., 2006).

Finally, we developed the concept of "shaping," which involves negotiating an individual proposal for career advancement that would change organizational practices or structures. Across multiple studies, we observed evidence of shaping as a process of leadership claiming (Derue \& Ashford, 2010) employed by both men and women. Our analyses suggest that successful shaping typically requires multi-party negotiations over extended periods of time in order to develop a coalition of support for the negotiator's proposed organizational change. We hypothesize that shaping may help a woman reduce resistance to her leadership claims because it tends to involve making a mutually beneficial, as opposed to competitive, case for why the organization should invest in her leadership potential and expand her authority (e.g., see Bowles \& Babcock, 2013).

\section{Limitations and Future Research Directions}

We believe the present research offers valuable insights and directions for future research, but we are mindful of its limitations. Our analyses relied on narrative accounts, which could be biased by retrospective sensemaking or social desirability. To move beyond our rudimentary conceptual framework to predictive models would require a longitudinal perspective on what and how men and women negotiate for career advancement. The diversity of organizational contexts in our study samples enhances the generalizability of our findings, but more targeted research is needed to identify contextual factors that inhibit and facilitate men's and women's career negotiations. Finally, our samples are biased toward the experiences of high-achieving professionals. We should widen our investigation to include opportunities and barriers for less elite workers to negotiate their pay, role, and work-family conflicts. Deeper 
exploration of early-stage and mid-level career negotiation processes would illuminate better the role of negotiation in professional women's employment trajectory and continuity. Less educated workers may gain more from collective than individual negotiations.

\section{Practical Implications}

Focusing narrowly on pay negotiations biases our image of women as negotiators and our understanding of how negotiation contributes to gender gaps in pay and authority (Bowles \& McGinn, 2008) — both in the academic literature and in the public consciousness. With a focus on women's deficits in pay negotiations, the policy response has been to launch nationwide training programs to teach women to negotiate more effectively for higher pay (Paquette, 2015). Such interventions communicate that gender inequality is a problem of "fixing the women" (Ely \& Meyerson, 2000), which is inaccurate and feeds gender stereotypes.

This work has important implications for how we train and advise students and executives in their career negotiations. A great deal of insight has been gained from two-party, issues-and-options “asking” simulations of job offer negotiations, but we should also teach cases that illuminate how one negotiates for role advancements through the multiparty processes of bending and shaping. We should help women use negotiation not only to ask for more pay and benefits, but also to negotiate their roles and workloads to remain continuously employed and upwardly mobile. We should also work with leaders in the government and private sectors to implement public and organizational policies that open doors for women and men to negotiate mutually beneficial work arrangements with their organizations that help them grow and contribute professionally as whole people. 


\section{REFERENCES}

Acker, J. 1990. Hierarchies, jobs, bodies: A theory of gendered organizations. Gender \& Society, 4(2): 139-158.

Al Dabbagh, M., Bowles, H. R., \& Thomason, B. 2016. Status reinforcement in emerging economies: The psychological experience of local candidates striving for global employment. Organization Science, 27(6): 1453-1471.

Amanatullah, E. T., \& Morris, M. W. 2010. Negotiating gender roles: Gender differences in assertive negotiating are mediated by women's fear of backlash and attenuated when negotiating on behalf of others. Journal of Personality and Social Psychology, 98(2): $256-267$.

Arthur, M. B., Hall, D. T., \& Lawrence, B. S. (Eds.). 1989. Handbook of career theory. New York, NY: Cambridge University Press.

Artz, B., Goodall, A. H., \& Oswald, A. J. 2018. Do women ask? Industrial Relations: $\boldsymbol{A}$ Journal of Economy and Society, 57(4): 611-636.

Babcock, L., \& Laschever, S. 2003. Women don't ask: Negotiation and the gender divide. Princeton, NJ: Princeton University Press.

Barley, S. R. 1989. Careers, identities and institutions: The legacy of the Chicago School of Sociology. In M. B. Arthur, D. T. Hall, \& B. S. Lawrence (Eds.), Handbook of career theory: 44-65. New York: Cambridge University Press.

Bear, J. 2011. "Passing the buck": Incongruence between gender role and topic leads to avoidance of negotiation. Negotiation and Conflict Management Research, 4(1): 47-72.

Bear, J. 2018. The caregiving ambition framework. Academy of Management Review. https://doi.org/10.5465/amr.2016.0424.

Bendersky, C., \& McGinn, K. L. 2010. Perspective—open to negotiation: Phenomenological 
assumptions and knowledge dissemination. Organization Science, 21(3): 781-797.

Berdahl, J. L., \& Moon, S. H. 2013. Workplace mistreatment of middle class workers based on sex, parenthood, and caregiving. Journal of Social Issues, 69(2): 341-366.

Blair-Loy, M., \& Wharton, A. S. 2002. Employees' use of work-family policies and the workplace social context. Social Forces, 80(3): 813-845.

Blau, F. D., \& Kahn, L. M. 2017. The gender wage gap: Extent, trends, and explanations. Journal of Economic Literature, 55(3): 789-865.

Bowles, H. R. 2012. Claiming authority: How women explain their ascent to top business leadership positions. Research in Organizational Behavior, 32: 189-212.

Bowles, H. R., \& Babcock, L. 2013. How can women escape the compensation negotiation dilemma? Relational accounts are one answer. Psychology of Women Quarterly, 37(1): 80-96.

Bowles, H. R., Babcock, L., \& Lai, L. 2007. Social incentives for gender differences in the propensity to initiate negotiations: Sometimes it does hurt to ask. Organizational Behavior and Human Decision Processes, 103(1): 84-103.

Bowles, H. R., Babcock, L., \& McGinn, K. L. 2005. Constraints and triggers: Situational mechanics of gender in negotiation. Journal of Personality and Social Psychology, 89(6): 951-965.

Bowles, H. R., \& McGinn, K. L. 2008. Gender in job negotiations: A two-level game. Negotiation Journal, 24: 393-410.

Brescoll, V. L., Dawson, E., \& Uhlmann, E. L. 2010. Hard won and easily lost: The fragile status of leaders in gender-stereotype-incongruent occupations. Psychological Science, 21(11): $1640-1642$.

Derue, D. S., \& Ashford, S. J. 2010. Who will lead and who will follow? A social process of 
leadership identity construction in organizations. Academy of Management Review, 35(4): 627-647.

Dutton, J. E., \& Ashford, S. J. 1993. Selling issues to top management. The Academy of Management Review, 18(3): 397-428.

Eagly, A. H., \& Carli, L. L. 2007. Through the labyrinth: The truth about how women become leaders. Cambridge, MA: Harvard Business Press.

Edmondson, A. C., \& McManus, S. E. 2007. Methodological fit in management field research. Academy of Management Review, 32: 1155-1179.

Eisenhardt, K. M. 1989. Building theories from case study research. The Academy of Management Review, 14(4): 532.

Ely, R. J., \& Meyerson, D. E. 2000. Theories of gender in organizations: A new approach to organizational analysis and change. Research in Organizational Behavior, 22: 103-151.

Feldman, M. S., \& Pentland, B. T. 2003. Reconceptualizing organizational routines as a source of flexibility and change. Administrative Science Quarterly, 48(1): 94-118.

Frone, M. R., Russell, M., \& Cooper, M. L. 1992. Antecedents and outcomes of work-family conflict: Testing a model of the work-family interface. Journal of Applied Psychology, 77(1): 65-78.

Gerhart, B., \& Rynes, S. 1991. Determinants and consequences of salary negotiations by male and female MBA graduates. Journal of Applied Psychology, 76: 256-262.

Gioia, D., \& Poole, P. 1984. Scripts in organizational behavior. Academy of Management Review, 9(3): 449-459.

Goldin, C. 2006. The quiet revolution that transformed women's employment, education, and family. The American Economic Review, 96(2): 1-21.

Goldin, C. 2014. A grand gender convergence: Its last chapter. American Economic Review, 
104(4): 1091-1119.

Gray, M. P., \& O’Brien, K. M. 2007. Advancing the Assessment of Women's Career Choices: The Career Aspiration Scale. Journal of Career Assessment, 15(3): 317-337.

Greenberg, D., \& Landry, E. M. 2011. Negotiating a flexible work arrangement: How women navigate the influence of power and organizational context. Journal of Organizational Behavior, 32(8): 1163-1188.

Hall, D. T. 1972. A model of coping with role conflict: The role behavior of college educated women. Administrative Science Quarterly, 17(4): 471-486.

Hausmann, R., \& Tyson, L. D. 2013. The global gender gap report. Geneva, Switzerland: World Economic Forum.

Heilman, M. E. 1983. Sex bias in work settings: The Lack of Fit model. Research in Organizational Behavior, 5: 269-298.

Henrich, J., Heine, S. J., \& Norenzayan, A. 2010. Most people are not WEIRD. Nature, 466: 29.

Hernandez, M., Avery, D. R., Volpone, S. D., \& Kaiser, C. R. 2018. Bargaining while Black: The role of race in salary negotiations. Journal of Applied Psychology, No Pagination Specified-No Pagination Specified.

Hornung, S., \& Rousseau, D. M. 2008. Creating flexible work arrangements through idiosyncratic deals. Journal of Applied Psychology, 93(3): 655-664.

Ibarra, H. 1993. Personal networks of women and minorities in management: A conceptual framework. Academy of Management Review, 18: 56-87.

Jones, D. 2010. A WEIRD view of human nature skews psychologists'studies. Science, 328(5986): 1627.

Kaplan, A. 2017. The conduct of inquiry: Methodology for behavioural science. London, England: Routledge. https://doi.org/10.4324/9781315131467. 
Kelly, E. L., Ammons, S. K., Chermack, K., \& Moen, P. 2010. Gendered challenge, gendered response: Confronting the ideal worker norm in a white-collar organization. Gender $\boldsymbol{\&}$ Society, 24(3): 281-303.

Kelly, E. L., \& Kalev, A. 2006. Managing flexible work arrangements in US organizations: Formalized discretion or 'a right to ask.' Socio-Economic Review, 4(3): 379-416.

Kolb, D., \& McGinn, K. 2009. Beyond gender and negotiation to gendered negotiations. Negotiation and Conflict Management Research, 2(1): 1-16.

Kray, L. J., \& Gelfand, M. J. 2009. Relief versus regret: The effect of gender and negotiating norm ambiguity on reactions to having one's first offer accepted. Social Cognition, 27(3): 418-436.

Kugler, K. G., Reif, J. A. M., Kaschner, T., \& Brodbeck, F. C. 2018. Gender differences in the initiation of negotiations: A meta-analysis. Psychological Bulletin, 144(2): 198-222.

Lax, D. A., \& Sebenius, J. K. 1986. The manager as negotiator: Bargaining for cooperation and competitive gain. New York, NY: Free Press.

Leibbrandt, A., \& List, J. A. 2014. Do women avoid salary negotiations? Evidence from a largescale natural field experiment. Management Science, 61: 2016-2024.

Leslie, L. M., King, E. B., \& Clair, J. A. 2019. Work-life ideologies: The contextual basis and consequences of beliefs about work and life. Academy of Management Review, 44(1): $72-98$.

Leslie, L. M., Manchester, C. F., Park, T.-Y., \& Mehng, S. A. 2012. Flexible work practices: A source of career premiums or penalties? Academy of Management Journal, 55(6): 14071428.

Lyness, K. S., \& Erkovan, H. E. 2016. The changing dynamics of careers and the work-family interface. In T. D. Allen \& L. T. Eby (Eds.), Oxford Handbook of Work and Family: 
376-388. New York, NY: Oxford University Press.

Mainiero, L. A., \& Sullivan, S. E. 2005. Kaleidoscope careers: An alternate explanation for the “opt-out” revolution. Academy of Management Perspectives, 19(1): 106-123.

Mazei, J., Hüffmeier, J., Freund, P. A., Stuhlmacher, A. F., Bilke, L., et al. 2015. A metaanalysis on gender differences in negotiation outcomes and their moderators. Psychological Bulletin, 141(1): 85-104.

Miner, A. S. 1987. Idiosyncratic jobs in formalized organizations. Administrative Science Quarterly, 32(3): 327-351.

Mitchell, S. M., \& Hesli, V. L. 2013. Women don't ask? Women don't say no? Bargaining and service in the political science profession. Political Science \& Politics, 46(2): 355-369.

Moghadam, V. M. 2004. Patriarchy in transition: Women and the changing family in the Middle East. Journal of Comparative Family Studies, 35(2): 137-162.

Neale, M. A. 1997. New recruit. Evanston, IL: Dispute Resolution Research Center, Northwestern University.

Paquette, D. 2015, November 13. Boston is offering free negotiation classes to every woman who works in the city. The Washington Post.

Perlow, L. A., \& Kelly, E. L. 2014. Toward a model of work redesign for better work and better life. Work and Occupations, 41(1): 111-134.

Phillips, S. D., \& Imhoff, A. R. 1997. Women and career development: A decade of research. Annual Review of Psychology, 48(1): 31-59.

Raiffa, H. 1982. The art and science of negotiation. Cambridge, MA: Harvard University Press.

Reid, E. 2015. Embracing, passing, revealing, and the ideal worker image: How people navigate expected and experienced professional identities. Organization Science, 26(4): $997-$ 1017. 
Ridgeway, C. L. 2011. Framed by gender: How gender inequality persists in the modern world. New York: Oxford University Press.

Rousseau, D. M. 2005. I-deals, idiosyncratic deals employees bargain for themselves. Armonk, NY: M.E. Sharpe.

Rousseau, D. M., Ho, V. T., \& Greenberg, J. 2006. I-deals: Idiosyncratic terms in employment relationships. The Academy of Management Review, 31(4): 977-994.

Rudman, L. A., \& Mescher, K. 2013. Penalizing men who request a family leave: Is flexibility stigma a femininity stigma? Journal of Social Issues, 69(2): 322-340.

Small, D. A., Gelfand, M., Babcock, L., \& Gettman, H. 2007. Who goes to the bargaining table? The influence of gender and framing on the initiation of negotiation. Journal of Personality and Social Psychology, 93(4): 600-613.

Spradley, J. P. 1979. The ethnographic interview. Belmont, CA: Wadsworth Publishing Company.

Strauss, A., \& Corbin, J. 1998. Basics of qualitative research: Procedures and techniques for developing grounded theory (2nd ed.). Thousand Oaks, CA: Sage Publications.

Thompson, L. L. 2005. The mind and heart of the negotiator (3rd ed.). Upper Saddle River, N.J.: Prentice Hall.

Vandello, J. A., Hettinger, V. E., Bosson, J. K., \& Siddiqi, J. 2013. When equal isn't really equal: The masculine dilemma of seeking work flexibility. Journal of Social Issues, 69(2): 303-321.

Wrzesniewski, A., \& Dutton, J. E. 2001. Crafting a job: Revisioning employees as active crafters of their work. Academy of Management Review, 26(2): 179-201.

Wrzesniewski, A., Dutton, J. E., \& Debebe, G. 2003. Interpersonal sensemaking and the meaning of work. Research in Organizational Behavior, 25: 93-135. 


\section{TABLE 1. Descriptive Statistics on Study Samples}

\begin{tabular}{|c|c|c|c|c|c|c|c|}
\hline & Study 1 & Study 2 & Study 3 & \multicolumn{2}{|c|}{ Study 4} & Study 5 & Study 6 \\
\hline $\begin{array}{l}\text { Organizational } \\
\text { Context }\end{array}$ & $\begin{array}{c}\text { Federal } \\
\text { Government }\end{array}$ & Corporate & $\begin{array}{c}\text { Corporate \& } \\
\text { Entrepreneurial }\end{array}$ & \multicolumn{2}{|c|}{ Corporate \& Entrepreneurial } & $\begin{array}{l}\text { Govt, Private, \& } \\
\text { Nonprofit Sector }\end{array}$ & $\begin{array}{l}\text { Govt, Private, \& } \\
\text { Nonprofit Sector }\end{array}$ \\
\hline Respondents & $\begin{array}{l}\text { Senior Civil } \\
\text { Servants }\end{array}$ & Partners & Senior Executives & Executives & $\begin{array}{l}\text { Non- } \\
\text { Executives }\end{array}$ & Senior Executives & $\begin{array}{l}\text { Early/Mid-Career } \\
\text { Professionals }\end{array}$ \\
\hline$N$ & 49 & 156 & 50 & 32 & 13 & 58 & 140 \\
\hline $\begin{array}{l}\text { Global Region of } \\
\text { Employment }\end{array}$ & North America & North America & $\begin{array}{c}\text { Asia, North } \\
\text { America }(96 \%)\end{array}$ & \multicolumn{2}{|c|}{$\begin{array}{l}\text { Middle East \& North Africa } \\
\text { (MENA) }\end{array}$} & $\begin{array}{l}\text { Africa, Asia, } \\
\text { Europe, Oceana, } \\
\text { North \& South } \\
\text { America }\end{array}$ & $\begin{array}{l}\text { Africa, Asia, } \\
\text { Europe, Oceana, } \\
\text { North \& South } \\
\text { America }\end{array}$ \\
\hline$\%$ North America & $100 \%$ & $100 \%$ & $96 \%$ & $0 \%$ & $0 \%$ & $59 \%$ & $68 \%$ \\
\hline$\%$ Female & $45 \%$ & $57 \%$ & $100 \%$ & $100 \%$ & $100 \%$ & $100 \%$ & $51 \%$ \\
\hline $\begin{array}{l}\text { Average Years of } \\
\text { Experience }\end{array}$ & 21 & 22 & 28 & 22 & 18 & (not reported) & 11 \\
\hline Sample Titles & $\begin{array}{l}\text { Director, Chief, } \\
\text { Division Head, } \\
\text { Executive Officer, } \\
\text { Field Office } \\
\text { Director, Deputy } \\
\text { Chief }\end{array}$ & $\begin{array}{c}\text { Partners with and } \\
\text { without } \\
\text { leadership roles } \\
\text { within } \\
\text { partnership (e.g., } \\
\text { head of specific } \\
\text { region or market) }\end{array}$ & $\begin{array}{l}\text { Board Chair, } \\
\text { Chief Executive } \\
\text { Officer (CEO), } \\
\text { Chief Financial } \\
\text { Officer (CFO), } \\
\text { Director, } \\
\text { President }\end{array}$ & $\begin{array}{l}\text { Board Chair, } \\
\text { CEO, CFO, } \\
\text { Director, } \\
\text { President }\end{array}$ & $\begin{array}{l}\text { Business } \\
\text { Manager, } \\
\text { Center } \\
\text { Director, } \\
\text { Research } \\
\text { Director }\end{array}$ & $\begin{array}{c}\text { CEO, Deputy } \\
\text { Director, Director, } \\
\text { Executive Director, } \\
\text { Managing Director, } \\
\text { Member of } \\
\text { Parliament }\end{array}$ & (not reported) \\
\hline $\begin{array}{l}\text { Advanced Degree } \\
\text { (e.g., } M B A, M P A, \\
M P P, J D, P h D)\end{array}$ & $56 \%$ & (not reported) & $60 \%$ & $57 \%$ & $50 \%$ & (not reported) & $100 \%$ \\
\hline Working Parent & (not reported) & $\begin{array}{l}75 \% \text { men } \\
58 \% \text { women }\end{array}$ & $\begin{array}{l}60 \% \text { corporate } \\
92 \% \text { entrepren'l }\end{array}$ & $67 \%$ & $100 \%$ & (not reported) & $\begin{array}{l}36 \% \text { men } \\
18 \% \text { women }\end{array}$ \\
\hline
\end{tabular}




\section{TABLE 2. Explanation of Asking, Bending, and Shaping Codes with Sample Quotes from Studies 1 and 3}

\section{Sample Quotes from Study 1}

Sample Quotes from Study 3

Ask: Employee makes a proposal for an individual allowance or authorization in line with organization norms or standards

Role Asking: "So, in terms of negotiation, the first step [was] to talk with my boss who has to support me in the [career-development] program. ... The question is, 'I'm thinking of doing this. What do you think?' ... It wouldn't be unreasonable to get a response saying, 'Well, not right now, but here's what we can do...' ... I knew what they believed the requirements to be, ... and I convinced them that I had what it is they were looking for." (G11)
Role Asking: [Example of] "when to say to 'no' to something ... [that] would actually take you in the wrong direction from where you wanted to be. [Midway in rotation,] they said, '...We really need you back at headquarters.' ... [I said,] 'Nope,... I'm going to stay....because otherwise you'll never really understand how good I am at operations. And...it would be very disruptive [to the business].'...They said, 'OK.' (C16)

Bend: Employee makes a proposal for an individual allowance or authorization that deviates from standard organizational practice

Compensation Bending: "I said I couldn't move my family unless some kind of bridge was made financially. We went through a number of iterations... They weren't able to make up the entire difference, but issue a [bonus].” (G71)

Work-Family Bending: "I went to my boss and I said, 'I've made a decision that I'm going to apply...' He was really, really happy about it. I said, 'Well, there are some things that we need to negotiate if I do... Every other weekend I need to go home and take care of family...' I said, 'You will get a better product if I know that my family is taken care of."' (G43)

Role Bending: "To get to the [executive] level, I needed strong backing from a managing director [MD]... [One MD] discussed ... me moving [offices] so that he could then be a strong advocate for me... [My manager] didn't want me to move... [We agreed] I wouldn't move my stuff out of my office, but that all my time would be programmed by the [MD]." (G14)
Work-Family Bending: "I only once ever hit a wall on something, and it had to do with going back for my MBA [full time in other city]... I woke up one day, and... I said 'What the hell am I doing?' ... I went in and I said, 'I'm really sorry... I want to be with my family.' ... I had fully anticipated that that would be a showstopper...-and, you know what, it never was." (C8)

Role Bending. "I was hired to come ... for a programming job [at site A]... but I asked ... did they have a management training program in? ... They hired me as a management training candidate [in site B], which meant that I actually never programmed a computer." (C5)

Role Bending. "I remember making a deal with my boss ... saying I would do this if, in return at the end of every day, he would just sit down with me so I could ask him all the questions that I had pretended to know the answers to over the course of the day." (C22)

Shape: Employee makes a proposal for an individual allowance or authorization that would change organizational structures or practices for strategic purposes

Role Shaping: "I work for [one center], but ... my project affects people from all of the centers [in the agency]. ... I made the case that ... I needed to be... at the agency level. So, I spoke with the executive sponsor ... at the agency level... I told her what my reasons were ... [because] I'm the person who knows the most about it. ... I planted the seed... I was clearly the one who was pushing things around and it was more important to me than to anybody else, so I was very proactive in laying the ground work and giving people information that they could use to think about it and make a decision." (G47)
Role Shaping: "The person [in] my role basically has [business A] but they were not responsible for [B]. It was great at the beginning for me not to have [B] because I was learning [the business]... Over time I started feeling like, if I am responsible for [A], then I need to be responsible [B too]. So I just started making that known, that I felt for the good of the business there should be one management team [for A and B]... Over time, that logic was compelling... I don't think it had ever... crossed their minds that the business might function better if it was structured differently." (C20) 
TABLE 3. Descriptive Statistics for Survey Measures in Study 2

\begin{tabular}{|c|c|c|c|c|c|c|c|c|c|c|c|c|c|}
\hline & & & \multicolumn{2}{|l|}{ Partner } & \multirow[b]{2}{*}{$\begin{array}{l}\text { Bread- } \\
\text { winner }\end{array}$} & \multirow[b]{2}{*}{$\begin{array}{c}\text { Infant/ } \\
\text { Child }\end{array}$} & \multicolumn{3}{|c|}{ How Negotiate } & \multicolumn{4}{|c|}{ What Negotiate } \\
\hline & & & Female & Leader & & & Ask & Bend & Shape & $\begin{array}{l}\text { Role: } \\
\text { Client } \\
\end{array}$ & $\begin{array}{c}\text { Role: } \\
\text { Prof. Dev. }\end{array}$ & $\begin{array}{c}\text { Role: } \\
\text { Ldr. Role }\end{array}$ & Workload \\
\hline Partner & $\mathrm{P}$ & & & & & & & & & & & & \\
\hline Female & .57 & & 1.00 & & & & & & & & & & \\
\hline Leader & .31 & & -0.12 & 1.00 & & & & & & & & & \\
\hline Breadwinner & .67 & & $-0.28^{* *}$ & $0.18^{*}$ & 1.00 & & & & & & & & \\
\hline \multirow[t]{2}{*}{ Infant/Child } & .65 & & $-0.17^{*}$ & -0.13 & -0.11 & 1.00 & & & & & & & \\
\hline & median & IQR & & & & & & & & & & & \\
\hline \multicolumn{14}{|l|}{ How Negotiate a } \\
\hline Ask & 5 & $4-6$ & 0.01 & 0.06 & 0.05 & -0.06 & 1.00 & & & & & & \\
\hline Bend & 3.5 & $2-5$ & $0.26^{* *}$ & -0.08 & $-0.18^{*}$ & 0.12 & $0.19^{*}$ & 1.00 & & & & & \\
\hline Shape & 6 & $5-7$ & -0.00 & $0.27^{* *}$ & 0.03 & -0.05 & $0.27^{* *}$ & 0.15 & 1.00 & & & & \\
\hline \multicolumn{14}{|l|}{ What Negotiate ${ }^{b}$} \\
\hline Role: Client & 3 & $3-4$ & 0.02 & 0.05 & -0.00 & 0.01 & $0.37^{* *}$ & $0.20^{*}$ & $0.29^{* *}$ & 1.00 & & & \\
\hline Role: Prof Dev & 3 & $2-3$ & 0.05 & -0.07 & -0.02 & -0.02 & $0.38^{* *}$ & $0.29^{* *}$ & $0.30^{* *}$ & $0.56^{* *}$ & 1.00 & & \\
\hline Role: LdrRole & 3 & $2-4$ & 0.07 & 0.08 & 0.03 & -0.13 & $0.45^{* *}$ & 0.11 & $0.46^{* *}$ & $0.49^{* *}$ & $0.49^{* *}$ & 1.00 & \\
\hline Workload & 3 & $3-4$ & $0.19 *$ & -0.13 & -0.09 & 0.03 & $0.31^{* *}$ & $0.33^{* *}$ & 0.15 & $0.51^{* *}$ & $0.47^{* *}$ & $0.41^{* *}$ & 1.00 \\
\hline Job Offer & 2 & $1-3$ & $-0.21^{*}$ & 0.05 & 0.00 & 0.03 & $0.29^{* *}$ & 0.14 & $0.29^{* *}$ & $0.31^{* *}$ & $0.31^{* *}$ & $0.32^{* *}$ & $0.36^{* *}$ \\
\hline
\end{tabular}

a Measured on 7-pt agreement scale: $1=$ Strongly disagree, $7=$ Strongly agree

${ }^{\mathrm{b}}$ Measured on 4-pt frequency scale: $1=$ Never, $2=$ Once, $3=\mathrm{A}$ few times, $4=$ Several times

$* p<.05$

$* * p<.01$ 
FIGURE 1. Illustrative Patterns in Career Negotiation Accounts Across Studies, Coded by "What" (Role, Workload/WorkFamily Flexibility, Compensation/Job Offer) and "How" (Ask, Bend, Shape) Negotiated
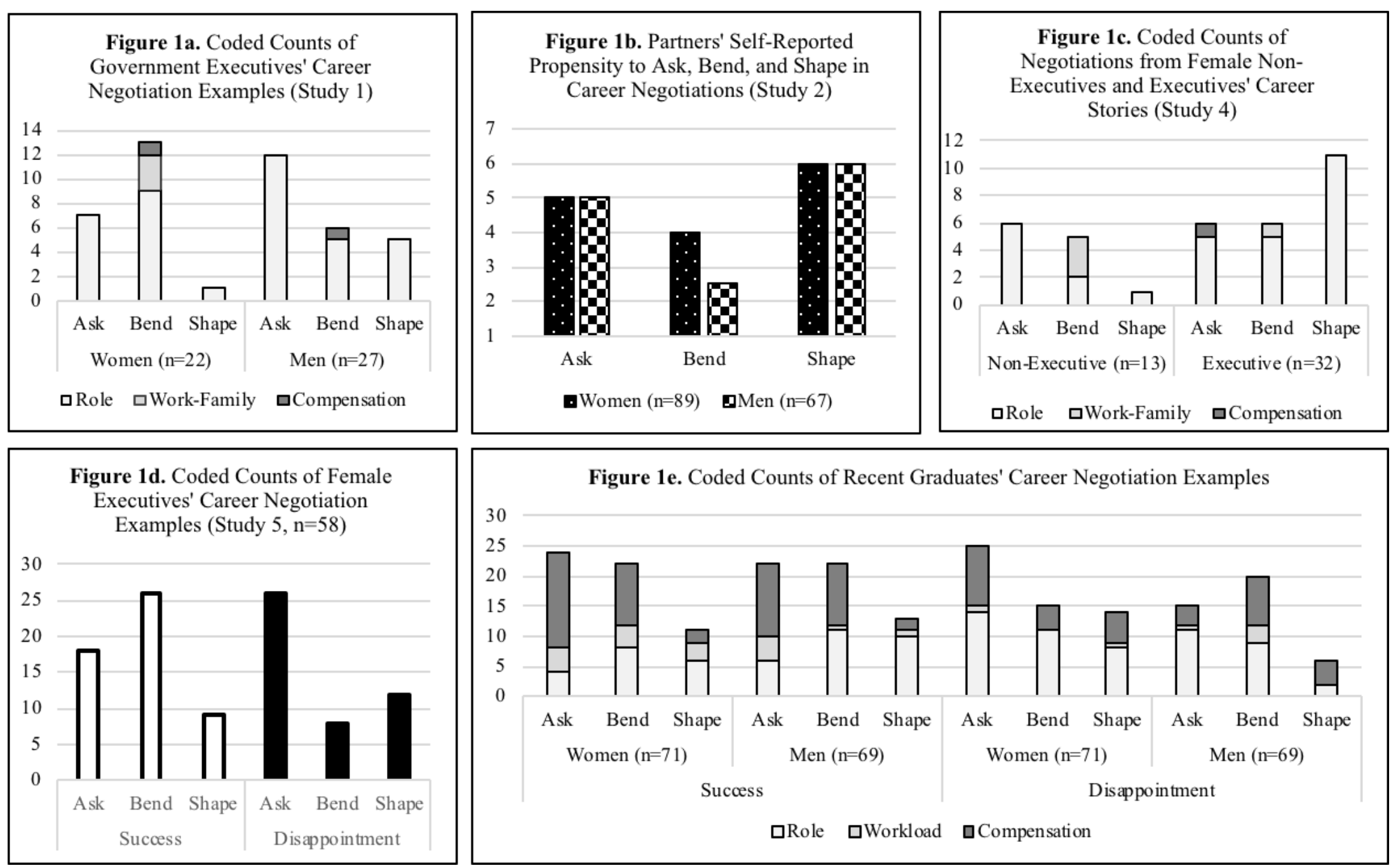
FIGURE 2. Conceptual Framework for Expanding Research on Gender in Career Negotiation in Organizations

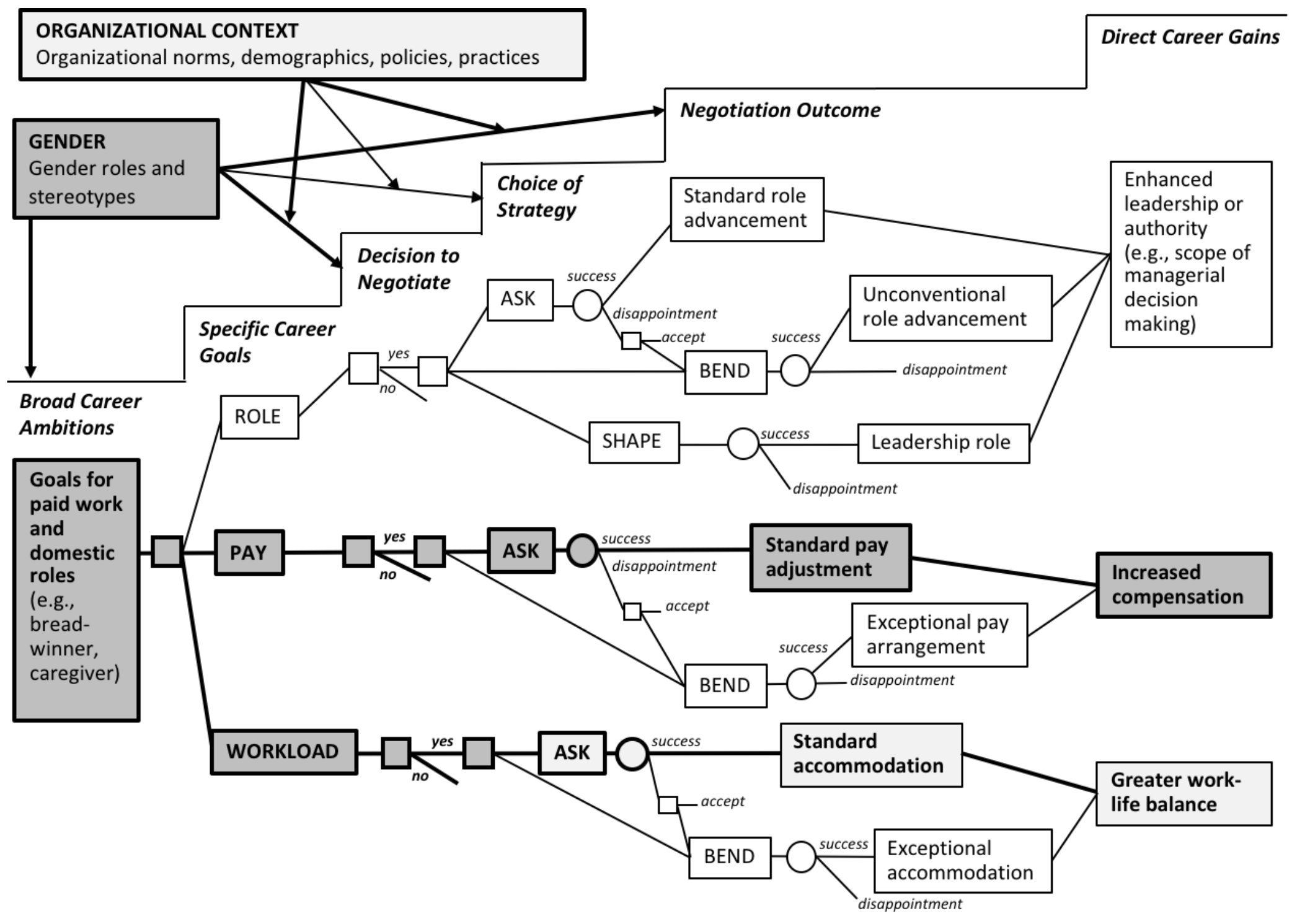


Hannah Riley Bowles (hannah_bowles@hks.harvard.edu) is the Roy E. Larsen Senior Lecturer in Public Policy and Management at the Harvard Kennedy School (HKS) and co-director of the HKS Women and Public Policy Program. Her research focuses on women's leadership advancement and on negotiation as a micro-mechanism of inequality. She received her doctorate from Harvard Business School.

Bobbi Thomason (bobbi.thomason@pepperdine.edu) is an Assistant Professor at Pepperdine Graziadio Business School. Her research explores work and careers in emerging markets and global contexts. She earned her PhD from Stanford University.

Julia B. Bear (julia.bear@stonybrook.edu) is an Associate Professor of Management at Stony Brook University. She received her $\mathrm{PhD}$ in organizational behavior from Carnegie Mellon University. In her research she focuses on the influence of gender on negotiation and conflict management, as well as on the causes of gender gaps in organizations. 